Article

\title{
Functionalized Biodegradable Polymers via Termination of Ring-Opening Polymerization by Acyl Chlorides
}

\author{
Ilya Nifant'ev 1,2,3,*®D, Andrey Shlyakhtin ${ }^{1}$, Vladimir Bagrov ${ }^{1}$, Evgeny Shaputkin ${ }^{1}$, Alexander Tavtorkin ${ }^{2}$ \\ and Pavel Ivchenko 1,2 (D) \\ 1 Chemistry Department, M.V. Lomonosov Moscow State University, 1-3 Leninskie Gory, \\ 119991 Moscow, Russia; shlyahtinav@mail.ru (A.S.); vlabag@yandex.ru (V.B.); \\ evgeny.shaputkin@yandex.ru (E.S.); phpasha1@yandex.ru (P.I.) \\ 2 Laboratory of Organometallic Catalysis, A.V. Topchiev Institute of Petrochemical Synthesis RAS, \\ 29 Leninsky Pr., 119991 Moscow, Russia; tavtorkin@yandex.ru \\ 3 Faculty of Chemistry, National Research University Higher School of Economics, 20 Miasnitskaya Str., \\ 101000 Moscow, Russia \\ * Correspondence: ilnif@yahoo.com; Tel.: +7-4959-394-098
}

Citation: Nifant'ev, I.; Shlyakhtin, A.; Bagrov, V.; Shaputkin, E.; Tavtorkin,

A.; Ivchenko, P. Functionalized Biodegradable Polymers via Termination of Ring-Opening Polymerization by Acyl Chlorides. Polymers 2021, 13, 868. https:// doi.org/10.3390/polym13060868

Academic Editor: Sergio Torres-Giner

Received: 13 February 2021

Accepted: 8 March 2021

Published: 11 March 2021

Publisher's Note: MDPI stays neutral with regard to jurisdictional claims in published maps and institutional affiliations.

Copyright: (c) 2021 by the authors. Licensee MDPI, Basel, Switzerland. This article is an open access article distributed under the terms and conditions of the Creative Commons Attribution (CC BY) license (https:// creativecommons.org/licenses/by/ $4.0 /)$.

\begin{abstract}
Aliphatic polyesters are an important class of polymeric materials for biomedical applications due to their versatile and tunable chemistry, biocompatibility and biodegradability. A capability of direct bonding with biomedically significant molecules, provided by the presence of the reactive end functional groups (FGs), is highly desirable for prospective polymers. Among FGs, $\mathrm{N}$-hydroxysuccinimidyl activated ester group (NHS) and maleimide fragment (MI) provide efficient covalent bonding with - NH- and -SH containing compounds. In our study, we found that NHS- and MI-derived acyl chlorides efficiently terminate living ring-opening polymerization of $\varepsilon$-caprolactone, L-lactide, ethyl ethylene phosphonate and ethyl ethylene phosphate, catalyzed by 2,6-di-tert-butyl-4methylphenoxy magnesium complex, with a formation of NHS- and MI-functionalized polymers at a high yields. Reactivity of these polymers towards amine- and thiol-containing model substrates in organic and aqueous media was also studied.
\end{abstract}

Keywords: conjugation; coordination catalysis; maleimide; NHS; N-hydroxysuccinimide; polycaprolactone; polyesters; polylactide; polyphosphoesters; ring-opening polymerization

\section{Introduction}

For contemporary pharmacy, tissue engineering and surgery the challenge is to step up implementation of the articles made from biocompatible and biodegradable polymers [1-4]. Besides the basic functions such as membrane permeability, mechanical strength and histocompatibility, a capability of direct binding with biomedically significant molecules such as drugs, hormones, growth and coagulation factors, enzymes, etc. would be highly desirable for prospective polymer-based articles [5-13].

Most of biomedically significant molecules contain -NH- or - $\mathrm{SH}$ fragments by which the chemical binding with polymer can be realized if the event that polymer contains reactive functional groups (FGs) $[5,9,14]$. Among FGs, N-hydroxysuccinimidyl activated ester group (NHS) and maleimide fragment (MI) were successfully applied for covalent bonding with -NH- and -SH containing compounds, respectively (Scheme 1a) [12,15-25].

Ring-opening polymerization of cyclic esters, phosphates and phosphonates (Scheme 1b) [26-35] results in the formation of polymers containing - $\mathrm{OH}$ end group. To date, a number of methods of the functionalization of -OH end group in separated polymers with a formation of NHS or MI derivatives have been implemented [36-43]. These methods are based on common protocols of the acylation of alcohols (Scheme 1c). 
(a)

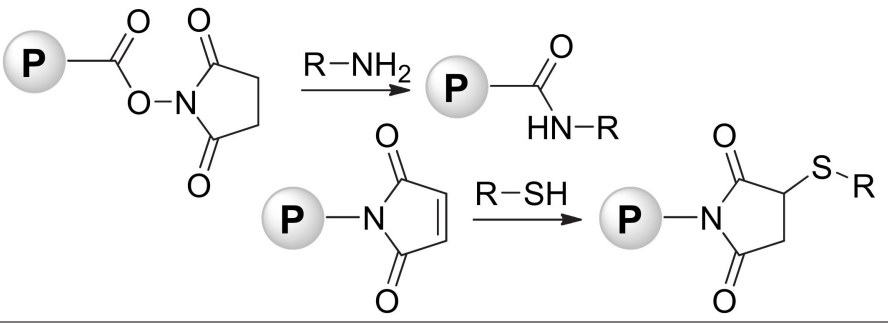

(b)
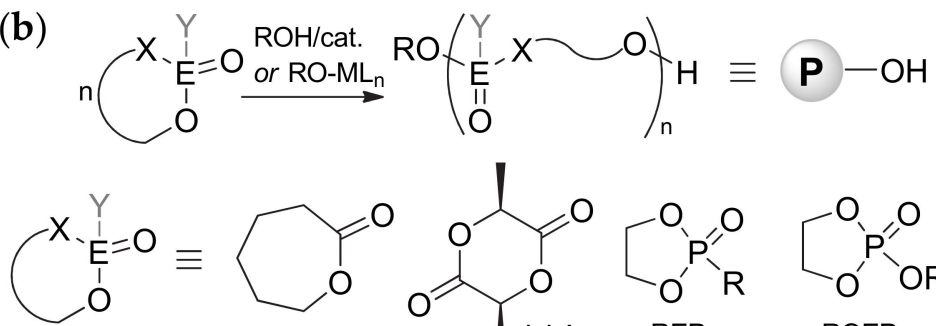

$\varepsilon \mathrm{CL}$<smiles>[R]P1(=O)OCCO1</smiles><smiles></smiles>

(c)

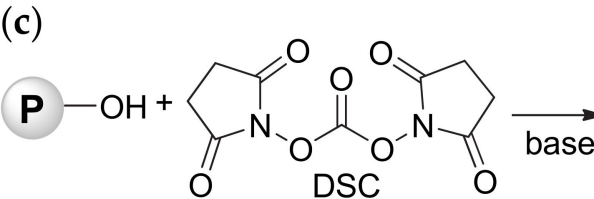<smiles>O=C(Oc1ccccc1)ON1C(=O)CCC1=O</smiles><smiles>O[Pb]</smiles><smiles>O=C(CC(=O)Oc1ccc(OC(=O)CC(=O)ON2C(=O)CCC2O)cc1)Oc1ccc(OC(=O)CC(=O)ON2C(=O)CCC2=O)cc1</smiles>

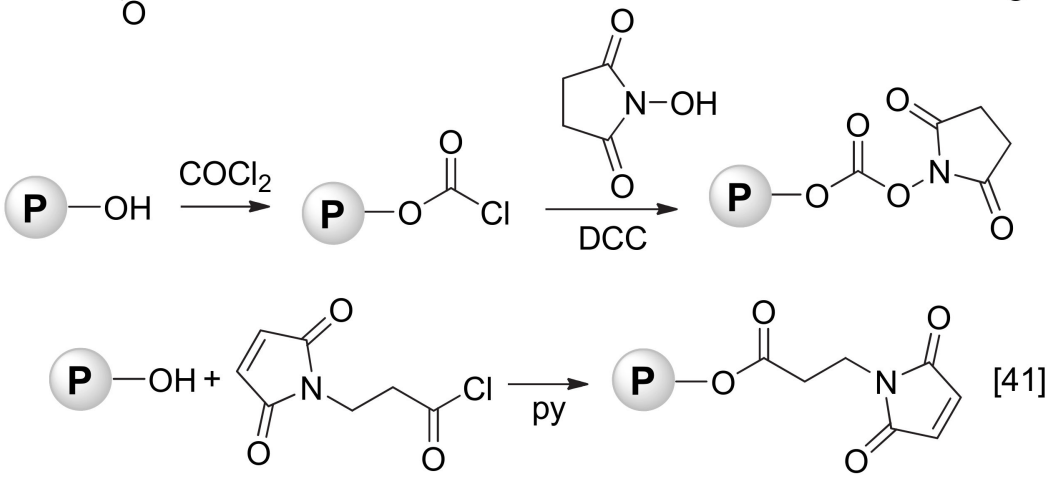

Scheme 1. (a) Reactivity of NHS (N-hydroxysuccinimidyl) and MI (maleimide) end groups; (b) ringopening polymerization (ROP) and common cyclic substrates; (c) known methods of the synthesis of NHS- and MI-functionalized polymers [36-45].

The methods presented in Scheme 1 do not necessarily lead to polymers that have $100 \%$ degree of functionalization even using large surpluses of the reagents and long reaction times. Considering the "living" nature of the ROP, catalyzed by a number of both organocatalysts and coordination catalysts, polymer functionalization involving activated chain-end alkoxy group seems reasonable. This idea was realized by Wurm et al. by the example of termination of 1,8-diazabicyclo[5.4.0]undec-7-ene (DBU)/ $\mathrm{BnO}\left(\mathrm{CH}_{2}\right)_{2} \mathrm{OH}$ catalyzed ROP of ethylene phosphonate or ethylene phosphate using $N, N^{\prime}$-disuccinimidyl carbonate (DSC) [37,44] (Scheme 2a). Stanford and Dove implemented this approach in ROP of L-lactide (L-LA), catalyzed by Al salen complexes and terminated by acyl chloride A with subsequent retro-Diels-Alder reaction (Scheme $2 b$ ), however, such functionalization required long time at elevated temperatures $\left(120 \mathrm{~h}, 70^{\circ} \mathrm{C}\right)[45,46]$. 
Recently, we demonstrated high efficiency of alkoxy $\mathrm{Mg}$ complexes of 2,6-di-tertbutyl-4-methylphenol (BHT-H) in "living" ROP of different cyclic esters, phosphates and phosphonates [47-55]. In this paper, we report that "living" alkoxy Mg-BHT chain end can be efficiently terminated under mild reaction conditions by acyl chlorides 1-4 (Scheme 2c) with simultaneous insertion of NHS and MI fragments, suitable for eventual interactions with -NH- and -SH containing compounds. NHS- and MI-functionalized polymers were studied in model reactions with isobutylamine $\left({ }^{\mathrm{i}} \mathrm{BuNH}_{2}\right)$ and methyl 2-mercaptoacetate $\left(\mathrm{HSCH}_{2} \mathrm{COOMe}\right)$ in organic and aqueous media to evaluate the potential of the chemical binding of these polymers with biomedically significant molecules.

(a)

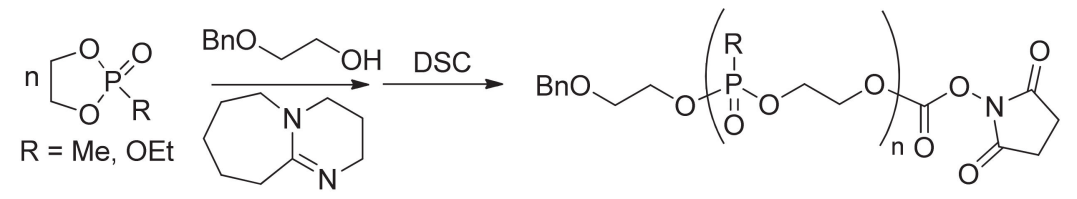

(b)
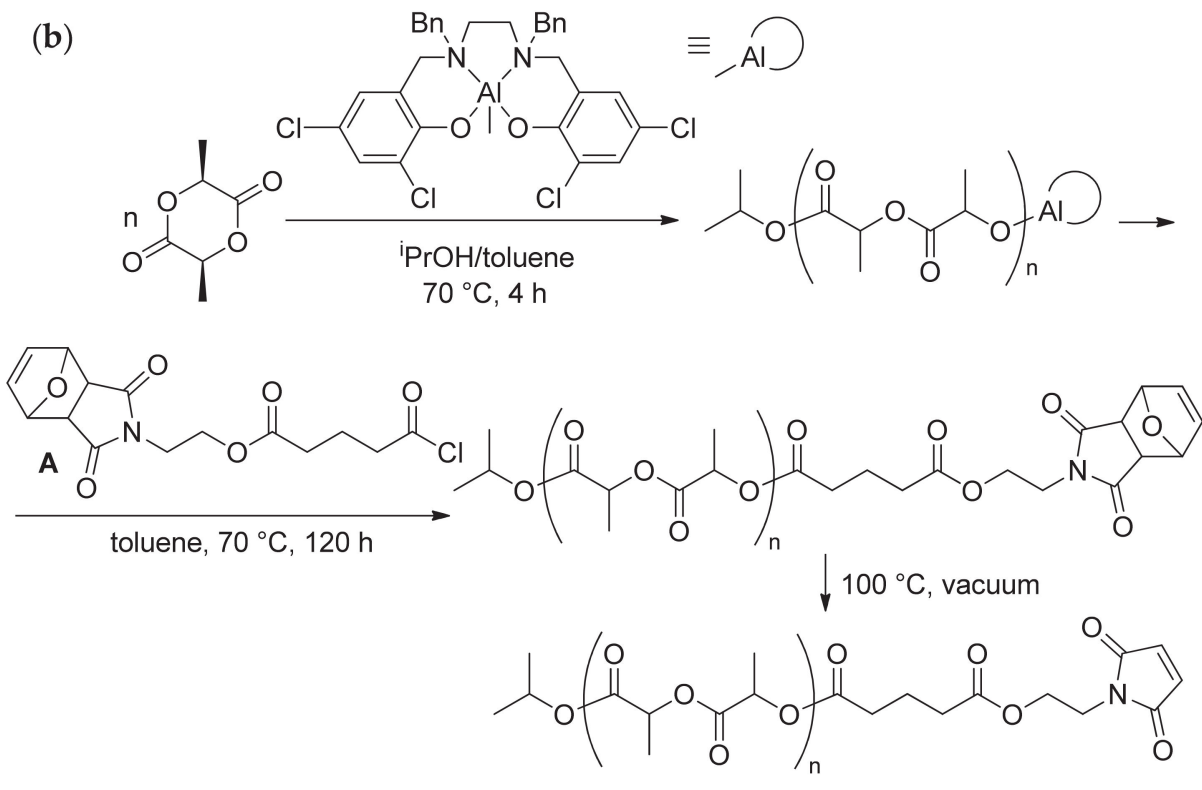

(c)<smiles>O=C(Cl)CCC(I)C(=O)ON1C(=O)CCC1=O</smiles><smiles>C[C@H](CC(=O)Cl)N1C(=O)C=CC1=O</smiles>

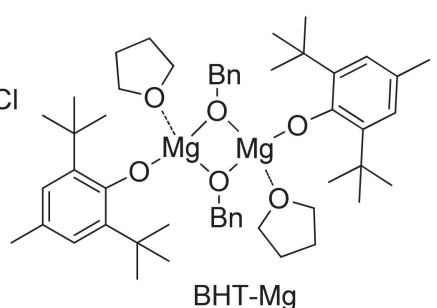

Scheme 2. (a) NHS functionalization of "living" polyphosphates and polyphosphonates [37,44]; (b) MI functionalization of "living" poly(L-LA) [42,46]; (c) NHS and MI substituted acyl chlorides and BHT-Mg catalyst used in the synthesis of NHS- and MI-terminated polymers [this work].

\section{Materials and Methods}

\subsection{General Experimental Remarks}

All of the synthetic and polymerization experiments were performed under a purified argon atmosphere. Tetrahydrofuran (THF), 1,4-dioxane, diethyl ether $\left(\mathrm{Et}_{2} \mathrm{O}\right)$ and $N, N, N-$ triethylamine $\left(\mathrm{Et}_{3} \mathrm{~N}\right)$ (Merck, Darmstadt, Germany) were refluxed with $\mathrm{Na}$ /benzophenone and distilled prior to use. $\mathrm{CH}_{2} \mathrm{Cl}_{2}$ (Prime Chemicals Group, Moscow, Russia) was washed with aqueous $\mathrm{Na}_{2} \mathrm{CO}_{3}$, stirred with $\mathrm{CaCl}_{2}$ powder, refluxed over $\mathrm{CaH}_{2}$ for $8 \mathrm{~h}$ and distilled. Acetonitrile (MeCN, Merck, Darmstadt, Germany) was stored over $\mathrm{K}_{2} \mathrm{CO}_{3}$, refluxed, and distilled from $\mathrm{CaH}_{2}$. $\varepsilon$-Caprolactone ( $\varepsilon \mathrm{CL}$, Merck, Darmstadt, Germany) was distilled 
prior to use under argon over $\mathrm{CaH}_{2}$. L-Lactide (L-LA, Merck, Darmstadt, Germany) was purified by recrystallization from toluene and sublimation. $\mathrm{N}, \mathrm{N}$-dimethylformamide (DMF), ethyl acetate (EtOAc), dimethoxymethane (DMM), acetyl chloride (AcCl), Nhydroxysuccinimide, succinic anhydride (SA), N,N-dimethylaminopyridine (DMAP), $\mathrm{HSCH}_{2} \mathrm{COOMe}^{\mathrm{i}} \mathrm{BuNH}_{2}, \mathrm{~N}, \mathrm{~N}^{\prime}$-dicyclohexylcarbodiimide (DCC), DSC, oxalyl chloride $\left(\mathrm{C}_{2} \mathrm{O}_{2} \mathrm{Cl}_{2}\right)$, thionyl chloride $\left(\mathrm{SOCl}_{2}\right)$, glutaric anhydride, and glycine were used as purchased (Merck, Darmstadt, Germany). 1,4-dioxane-2,6-dione [56], 2-(2,5-dioxo-2,5-dihydro$1 H$-pyrrol-1-yl)acetic acid (glycine maleimide) [57], 3-(2,5-dioxo-2,5-dihydro-1 $H$-pyrrol1-yl)propanoic acid [58], 2-ethyl-1,3,2-dioxaphospholane 2-oxide (ethyl ethylene phosphonate, EtEP) [59], 2-ethoxy-1,3,2-dioxaphospholane 2-oxide (ethyl ethylene phosphate, EtOEP) [60], 1,5,7-triazabicyclo[4.4.0]dec-5-ene (TBD) [61], and [(BHT)Mg( $\mu$-OBn)(THF) $]_{2}$ (BHT-Mg) [50] were synthesized according to the literature procedures. Benzoylated dialysis tubing D2272 (Merck, Darmstadt, Germany) was used for synthesis and purification of functionalized polymers.

$\mathrm{CDCl}_{3}$ (D 99.8\%, Cambridge Isotope Laboratories, Inc., Cambridge, MS, USA) was distilled over $\mathrm{P}_{2} \mathrm{O}_{5}$ and stored over 4 Å molecular sieves. DMSO- $\mathrm{d}_{6}$ (D 99.8\%, Cambridge Isotope Laboratories, Inc., Cambridge, MS, USA) was used as purchased. The ${ }^{1} \mathrm{H}(400 \mathrm{MHz})$, ${ }^{13} \mathrm{C}(101 \mathrm{MHz})$ and ${ }^{31} \mathrm{P}(162 \mathrm{MHz}) \mathrm{NMR}$ spectra were recorded on a Bruker AVANCE 400 spectrometer (Bruker, Billerica, MS, USA) at $20^{\circ} \mathrm{C}$. The chemical shifts were reported relative to the solvent residual peaks $\left(\delta=7.26 \mathrm{ppm}\right.$ for $\mathrm{CDCl}_{3}$ and $\delta=2.50 \mathrm{ppm}$ for DMSO- $\mathrm{d}_{6}$ ).

Size exclusion chromatography (SEC) was performed on an Agilent PL-GPC 220 chromatograph (Agilent Technologies, Santa Clara, CA, USA) equipped with a PLgel column, using THF (for $\varepsilon C L$, L-LA polymers) or DMF (for EtEP and EtOEP polymers) as the eluents $(1 \mathrm{~mL} / \mathrm{min})$. The measurements were recorded at $40^{\circ} \mathrm{C}$ with universal calibration using polystyrene standards ( $\varepsilon \mathrm{CL}$ and L-LA polymers, corrected by the factors of 0.56 for poly $(\varepsilon C L)$ and 0.58 for poly(L-LA)) or poly(ethylene glycol) standards (for EtEP and EtOEP polymers).

Elemental analysis $(\mathrm{C}, \mathrm{H}, \mathrm{N}, \mathrm{O})$ was performed on a Perkin Elmer Series II CHNS/O Analyzer 2400 (Perkin Elmer, Waltham, MS, USA).

\subsection{Synthesis of NHS- and MI-Functionalized Acyl Chlorides}

Except new compound 2, acyl chlorides 1, $\mathbf{3}$ and $\mathbf{4}$ have been obtained previously and typically used in situ, without separation and purification [41,62-64]. Out of these compounds, only acyl chloride 4 had been characterized by ${ }^{1} \mathrm{H}$ and ${ }^{13} \mathrm{C}$ NMR spectroscopy. In this section, we report NMR spectral data for $\mathbf{1}-\mathbf{4},{ }^{1} \mathrm{H}$ and ${ }^{13} \mathrm{C}$ NMR spectra of $\mathbf{1 - 4}$ are presented in Figures S1-S8 in the Supplementary Materials.

\subsubsection{Synthesis of 2,5-dioxopyrrolidin-1-yl 5-chloro-5-oxopentanoate $\mathbf{1}$}

Acyl chloride 1 was synthesized according to the modified literature procedure [61]. $\mathrm{N}$-hydroxysuccinimide (3.45 g, $30 \mathrm{mmol})$ was dissolved in THF (200 mL), DMAP (4.9 g, $40 \mathrm{mmol}$ ) was added with stirring. Resulting clear solution was cooled to $5{ }^{\circ} \mathrm{C}$, glutaric anhydride ( $3.42 \mathrm{~g}, 30 \mathrm{mmol})$ in THF solvent $(20 \mathrm{~mL})$ was added dropwise. The mixture was allowed to warm to room temperature (RT), stirred for $30 \mathrm{~min}$, and evaporated. EtOAc $(100 \mathrm{~mL}), \mathrm{H}_{2} \mathrm{O}(50 \mathrm{~mL})$ and conc. $\mathrm{HCl}(7 \mathrm{~mL})$ were added. Organic layer was separated, washed by water, dried over $\mathrm{MgSO}_{4}$ and evaporated under reduced pressure (Rotavapor R-100, BÜCHI Labortechnik AG, Flawil, Switzerland). The residue was recrystallized from $\mathrm{CHCl}_{3}$ and dried in vacuum (RZ 6 rotary vine pump, Vacuubrand GMBH, Wertheim, Germany). For 5-((2,5-dioxopyrrolidin-1-yl)oxy)-5-oxopentanoic acid the yield was $5.0 \mathrm{~g}$ (73\%). The acid was dissolved in $\mathrm{CH}_{2} \mathrm{Cl}_{2}(30 \mathrm{~mL})$, the solution was cooled to $0{ }^{\circ} \mathrm{C}$, then DMF $(5 \mu \mathrm{L})$ and $\mathrm{C}_{2} \mathrm{O}_{2} \mathrm{Cl}_{2}(3.9 \mathrm{~mL}, 45 \mathrm{mmol}, 1.5$ eq.) were added. After $2 \mathrm{~h}$ of stirring, the volatiles were removed under reduced pressure, and the residue was dried to constant weight at 0.01 Torr and ambient temperature. The yield was $4.6 \mathrm{~g}(62 \%)$, yellow solid. For $\mathrm{C}_{9} \mathrm{H}_{10} \mathrm{ClNO}_{5}$ calculated (\%): C, 43.65; H, 4.07; N, 5.66; O, 32.30. Found (\%): C, 43.68; H, $4.11 ; \mathrm{N}, 5.69 ; \mathrm{O}, 32.36 .{ }^{1} \mathrm{H} \mathrm{NMR}\left(\mathrm{CDCl}_{3}, 20{ }^{\circ} \mathrm{C}\right) \delta: 3.07\left(\mathrm{t},{ }^{3} \mathrm{~J}=7.1 \mathrm{~Hz}, 2 \mathrm{H}\right) ; 2.82(\mathrm{bs}, 4 \mathrm{H})$; 
$2.70\left(\mathrm{t},{ }^{3} \mathrm{~J}=7.1 \mathrm{~Hz}, 2 \mathrm{H}\right) ; 2.10\left(\mathrm{p},{ }^{3} \mathrm{~J}=7.1 \mathrm{~Hz}, 2 \mathrm{H}\right) .{ }^{13} \mathrm{C} \mathrm{NMR}\left(\mathrm{CDCl}_{3}, 20{ }^{\circ} \mathrm{C}\right) \delta: 173.31 ; 169.17$; $167.72 ; 45.36 ; 29.36 ; 25.64 ; 20.03$.

\subsubsection{Synthesis of 2,5-dioxopyrrolidin-1-yl 2-(2-chloro-2-oxoethoxy)acetate 2}

$\mathrm{N}$-hydroxysuccinimide (10 mmol, $1.15 \mathrm{~g})$ was dissolved in THF $(100 \mathrm{~mL})$, DMAP $(1.22 \mathrm{~g}, 10 \mathrm{mmol})$ was added with stirring. Resulting clear solution was cooled to $5{ }^{\circ} \mathrm{C}$, 1,4-dioxane-2,6-dione $(1.16 \mathrm{~g}, 10 \mathrm{mmol})$ in THF solvent $(10 \mathrm{~mL})$ was added dropwise. The mixture was allowed to warm to RT and stored for 2 days. The mixture was cooled to $5{ }^{\circ} \mathrm{C}$, DMF $(10 \mu \mathrm{L})$ and $\mathrm{C}_{2} \mathrm{O}_{2} \mathrm{Cl}_{2}(1.29 \mathrm{~mL}, 15 \mathrm{mmol}, 1.5$ eq.) were added within $2 \mathrm{~h}$. The reaction mixture was filtered off, the solution was evaporated under reduced pressure, the solid residue was washed by $\mathrm{Et}_{2} \mathrm{O}$, dissolved in minimal volume of benzene at $80^{\circ} \mathrm{C}$, filtered, and evaporated under reduced pressure. The residue was washed by $\mathrm{Et}_{2} \mathrm{O}$ and dried to constant weight at 0.01 Torr and ambient temperature. The yield was $0.31 \mathrm{~g}(25 \%)$. Melting point (M. p.) $100-102{ }^{\circ} \mathrm{C}$. For $\mathrm{C}_{8} \mathrm{H}_{8} \mathrm{ClNO}_{6}$ calculated (\%): C, 38.50; $\mathrm{H}, 3.23 ; \mathrm{N}, 5.61$; $\mathrm{O}, 38.46$. Found (\%): C, 38.46; H, 3.26; N, 5.62; O, 38.51. ${ }^{1} \mathrm{H}$ NMR $\left(\mathrm{CDCl}_{3}, 20{ }^{\circ} \mathrm{C}\right) \delta: 4.610$ $(\mathrm{s}, 2 \mathrm{H}) ; 4.607(\mathrm{~s}, 2 \mathrm{H}) ; 2.87(\mathrm{bs}, 4 \mathrm{H}) .{ }^{13} \mathrm{C} \mathrm{NMR}\left(\mathrm{CDCl}_{3}, 20{ }^{\circ} \mathrm{C}\right) \delta: 171.15 ; 168.71 ; 164.96 ; 75.44 ;$ $65.95 ; 25.69$.

\subsubsection{Synthesis of 2-(2,5-dioxo-2,5-dihydro-1H-pyrrol-1-yl)acetyl chloride 3}

Acyl chloride 3 was synthesized according to the modified literature procedure [63]. Glycine maleimide ( $1.55 \mathrm{~g}, 10 \mathrm{mmol})$ was refluxed with $\mathrm{SOCl}_{2}(7.3 \mathrm{~mL}, 100 \mathrm{mmol}, 10$ eq.) within $30 \mathrm{~min}$. The volatiles were removed under reduced pressure, toluene $(5 \mathrm{~mL})$ was added and removed under reduced pressure. The residue was dried to constant weight at 0.01 Torr and ambient temperature. The yield was $1.7 \mathrm{~g}(98 \%)$, pale yellow oil. For $\mathrm{C}_{6} \mathrm{H}_{4} \mathrm{ClNO}_{3}$ calculated (\%): $\mathrm{C}, 41.52 ; \mathrm{H}, 2.32 ; \mathrm{N}, 8.07 ; \mathrm{O}, 27.66$. Found (\%): $\mathrm{C}, 41.58 ; \mathrm{H}, 2.36$; $\mathrm{N}, 8.02 ; \mathrm{O}, 27.69 .{ }^{1} \mathrm{H} \mathrm{NMR}\left(\mathrm{CDCl}_{3}, 20{ }^{\circ} \mathrm{C}\right) \delta: 6.82(\mathrm{~s}, 2 \mathrm{H}) ; 4.64(\mathrm{~s}, 2 \mathrm{H}) .{ }^{13} \mathrm{C} \mathrm{NMR}\left(\mathrm{CDCl}_{3}\right.$, $\left.20^{\circ} \mathrm{C}\right) \delta: 169.27 ; 168.90 ; 134.72 ; 47.33$.

\subsubsection{Synthesis of 3-(2,5-dioxo-2,5-dihydro-1H-pyrrol-1-yl)propanoyl chloride 4}

Acyl chloride 3 was synthesized according to the modified literature procedure [64]. 3(2,5-dioxo-2,5-dihydro-1H-pyrrol-1-yl)propanoic acid [58] (0.44 g, $2.6 \mathrm{mmol})$ was dissolved in $\mathrm{CH}_{2} \mathrm{Cl}_{2}(15 \mathrm{~mL})$. DMF (5 $\left.\mu \mathrm{L}\right)$ was added, the solution was cooled to $-10{ }^{\circ} \mathrm{C}$, and $\mathrm{C}_{2} \mathrm{O}_{2} \mathrm{Cl}_{2}$ $(0.33 \mathrm{~mL}, 3.9 \mathrm{mmol}, 1.5 \mathrm{eq}$.) was added. The reaction mixture was allowed to warm to $\mathrm{RT}$, stirred for $4 \mathrm{~h}$, and evaporated under reduced pressure. The residue was dried to constant weight at 0.01 Torr and ambient temperature. The yield was $0.45 \mathrm{~g}(92 \%)$, yellow-green solid. For $\mathrm{C}_{7} \mathrm{H}_{6} \mathrm{ClNO}_{3}$ calculated (\%): C, 44.82; $\mathrm{H}, 3.22 ; \mathrm{N}, 7.47 ; \mathrm{O}, 25.59$. Found (\%): $\mathrm{C}$, 44.88; $\mathrm{H}, 3.27 ; \mathrm{N}, 7.43 ; \mathrm{O}, 25.65 .{ }^{1} \mathrm{H}$ NMR $\left(\mathrm{CDCl}_{3}, 20^{\circ} \mathrm{C}\right) \delta: 6.73(\mathrm{~s}, 2 \mathrm{H}) ; 3.85\left(\mathrm{t},{ }^{3} \mathrm{~J}=6.9 \mathrm{~Hz}\right.$, $2 \mathrm{H}) ; 3.24\left(\mathrm{t},{ }^{3} \mathrm{~J}=6.9 \mathrm{~Hz}, 2 \mathrm{H}\right) .{ }^{13} \mathrm{C} \mathrm{NMR}\left(\mathrm{CDCl}_{3}, 2{ }^{\circ} \mathrm{C}\right) \delta: 171.53 ; 170.09 ; 134.45 ; 44.95 ; 33.17$.

\subsection{Synthesis of NHS- and MI-Functionalized Polymers}

\subsubsection{Polymerization of $\varepsilon C L$ with Termination by DSC}

A preheated $30 \mathrm{~mL}$ glass ampoule was equipped with a magnetic stir bar and a septum and then filled with dry argon. $\varepsilon \mathrm{CL}(0.96 \mathrm{~mL}, 8.6 \mathrm{mmol}, 50$ eq.) was placed into the ampule, $\mathrm{CH}_{2} \mathrm{Cl}_{2}(2.3 \mathrm{~mL})$ was added. The mixture was cooled to $5{ }^{\circ} \mathrm{C}$, and $\mathrm{BHT}-\mathrm{Mg}$ (73 mg, $0.17 \mathrm{mmol} \mathrm{Mg}, 1$ eq.) in THF solvent $(1.0 \mathrm{~mL}$ ) was added (resulting concentration of $\varepsilon \mathrm{CL}$ was $2 \mathrm{M}$ ). After $4 \mathrm{~h}$ of stirring, the reaction mixture was cooled to $-20^{\circ} \mathrm{C}$, and DSC ( $218 \mathrm{mg}, 0.85 \mathrm{mmol}, 5$ eq.) in MeCN solvent ( $3 \mathrm{~mL}$ ) was added. After $3 \mathrm{~h}$ of stirring, the reaction mixture was filtered, the filtrate was evaporated to dryness under reduced pressure, dissolved in $\mathrm{CH}_{2} \mathrm{Cl}_{2}(5 \mathrm{~mL})$ and precipitated in dry $\mathrm{MeOH}(40 \mathrm{~mL})$. The polymer was filtered off and dried to constant weight at 0.01 Torr and ambient temperature. The yield was $0.80 \mathrm{~g}(81 \%) .{ }^{1} \mathrm{H} \mathrm{NMR}\left(\mathrm{CDCl}_{3}, 20^{\circ} \mathrm{C}\right) \delta: 7.34\left(\mathrm{~m}, 5 \mathrm{H}, \mathrm{C}_{6} \mathrm{H}_{5}\right) ; 5.10\left(\mathrm{~s}, 2 \mathrm{H}, \mathrm{PhCH}_{2}\right)$; $4.05\left(\mathrm{t},{ }^{3} \mathrm{~J}=6.7 \mathrm{~Hz}, 98 \mathrm{H},-\mathrm{OCH}_{2}-\right.$ of poly $(\varepsilon \mathrm{CL})$ ); $2.83\left(\mathrm{~s}, 1.33 \mathrm{H},-\mathrm{CH}_{2}-\right.$ of NHS); 2.30 $\left(\mathrm{t},{ }^{3} \mathrm{~J}=6.8 \mathrm{~Hz}, 99 \mathrm{H}, \mathrm{C}(\mathrm{O}) \mathrm{CH}_{2}\right.$ of poly $\left.(\varepsilon \mathrm{CL})\right) ; 1.64\left(\mathrm{~m}, 203 \mathrm{H},-\mathrm{CH}_{2}-\right.$ of $\left.\operatorname{poly}(\varepsilon \mathrm{CL})\right) ; 1.37$ $\left(\mathrm{p},{ }^{3} \mathrm{~J}=6.8 \mathrm{~Hz}, 100 \mathrm{H},-\mathrm{CH}_{2}-\right.$ of poly $\left.(\varepsilon \mathrm{CL})\right)$, see Figure $\mathrm{S} 9$ in the Supplementary Materials. 
2.3.2. Polymerization of $\varepsilon C L$ with Termination by SA Followed by the Reaction with $N$-hydroxysuccinimide/DCC

A preheated $30 \mathrm{~mL}$ glass ampoule was equipped with a magnetic stir bar (Merck, Darmstadt, Germany) and a septum and then filled with dry argon. $\varepsilon$ CL (0.96 mL, $8.6 \mathrm{mmol}$, 50 eq.) was placed into the ampule, $\mathrm{CH}_{2} \mathrm{Cl}_{2}(2.3 \mathrm{~mL})$ was added. The mixture was cooled to $5{ }^{\circ} \mathrm{C}$, BHT-Mg (73 mg, $0.17 \mathrm{mmol} \mathrm{Mg}, 1$ eq.) in THF solvent $(1.0 \mathrm{~mL})$ was added (resulting concentration of $\varepsilon C L$ was $2 \mathrm{M})$. After $4 \mathrm{~h}$ of stirring, a solution of $68 \mathrm{mg}$ SA $(0.68 \mathrm{mmol}$, 4 eq.) in THF solvent $(1.0 \mathrm{~mL})$ was added at $5{ }^{\circ} \mathrm{C}$. After $30 \mathrm{~min}$ of stirring at $5{ }^{\circ} \mathrm{C}$, polymer solution was precipitated twice in diethyl ether $(30 \mathrm{~mL})$ and subsequently dried to constant weight at 0.01 Torr and RT. The product was dissolved in THF $(4 \mathrm{~mL})$, then NHS (98 $\mathrm{mg}$, $0.85 \mathrm{mmol}, 5$ eq.) in THF solvent $(2 \mathrm{~mL})$ and DCC (175 mg, $0.85 \mathrm{mmol}, 5$ eq. $)$ in THF solvent $(2 \mathrm{~mL})$ were added subsequentially. After stirring overnight, the reaction mixture was filtered, the filtrate was precipitated in $\mathrm{Et}_{2} \mathrm{O}(50 \mathrm{~mL})$. The polymer was filtered off and dried to constant weight at 0.01 Torr and RT. The yield was $0.75 \mathrm{~g}(76 \%)$. ${ }^{1} \mathrm{H} \mathrm{NMR}$ $\left(\mathrm{DMSO}_{6} \mathrm{~d}_{6}, 2{ }^{\circ} \mathrm{C}\right) \delta: 7.35\left(\mathrm{~m}, 5 \mathrm{H}, \mathrm{C}_{6} \mathrm{H}_{5}\right) ; 5.07\left(\mathrm{~s}, 2 \mathrm{H}, \mathrm{PhCH}_{2}\right) ; 3.98\left(\mathrm{t}, 119 \mathrm{H},-\mathrm{OCH}_{2}-\right.$ of poly $(\varepsilon \mathrm{CL})) ; 2.92\left(\mathrm{t},{ }^{3} \mathrm{~J}=6.3 \mathrm{~Hz}, 1.10 \mathrm{H},-\mathrm{C}(\mathrm{O})\left(\mathrm{CH}_{2}\right)_{2} \mathrm{C}(\mathrm{O})-\right) ; 2.80\left(\mathrm{~s}, 2.06 \mathrm{H},-\mathrm{CH}_{2}-\right.$ of NHS); $2.66\left(\mathrm{t},{ }^{3} \mathrm{~J}=6.3 \mathrm{~Hz}, 1.10 \mathrm{H},-\mathrm{C}(\mathrm{O})\left(\mathrm{CH}_{2}\right)_{2} \mathrm{C}(\mathrm{O})-\right) ; 2.26\left(\mathrm{t}, 117 \mathrm{H}, \mathrm{C}(\mathrm{O}) \mathrm{CH}_{2}\right.$ of poly $\left.(\varepsilon \mathrm{CL})\right) ; 1.54$ $\left(\mathrm{m}, 239 \mathrm{H},-\mathrm{CH}_{2}-\right.$ of poly $\left.(\varepsilon \mathrm{CL})\right) ; 1.29\left(\mathrm{p}, 121 \mathrm{H},-\mathrm{CH}_{2}-\right.$ of poly $\left.(\varepsilon \mathrm{CL})\right)$, see Figure S10 in the Supplementary Materials.

\subsubsection{Polymerization of $\varepsilon C L$ with Termination by $\mathbf{1}-\mathbf{4}$}

A preheated $30 \mathrm{~mL}$ glass ampoule was equipped with a magnetic stir bar and a septum and then filled with dry argon. $\varepsilon \mathrm{CL}(2.30 \mathrm{~mL}, 20.8 \mathrm{mmol}, 120$ eq.) was placed into the ampule, $\mathrm{CH}_{2} \mathrm{Cl}_{2}$ was added to total volume of $8.4 \mathrm{~mL}$. The mixture was cooled to $5{ }^{\circ} \mathrm{C}$, BHT-Mg (73 mg, $0.17 \mathrm{mmol} \mathrm{Mg,} 1$ eq.) in THF solvent $(2.0 \mathrm{~mL}$ ) was added (resulting concentration of $\varepsilon \mathrm{CL}$ was $2 \mathrm{M})$. After $4 \mathrm{~h}$ of stirring, chloroanhydride (0.69 mmol, 4 eq.) in $\mathrm{CH}_{2} \mathrm{Cl}_{2}$ solvent $(2 \mathrm{~mL}$ ) was added. The mixture was allowed to warm to $\mathrm{RT}$ and stirred for $8 \mathrm{~h}$. Reaction mixture was evaporated twice with $\mathrm{CH}_{2} \mathrm{Cl}_{2}$ for removal of THF. The residue was dissolved in $\mathrm{CH}_{2} \mathrm{Cl}_{2}(40 \mathrm{~mL})$, washed by $0.7 \mathrm{M}$ aq. $\mathrm{HCl}$, by water, dried over $\mathrm{MgSO}_{4}$ and filtered. The filtrate was evaporated to residual volume of $20 \mathrm{~mL}$ and poured into $\mathrm{Et}_{2} \mathrm{O}(100 \mathrm{~mL})$. The polymer was filtered off and dried to constant weight at 0.01 Torr and RT. The yields were 2.31 (95\%), $1.83(75 \%), 2.11(87 \%)$, and $1.89 \mathrm{~g}(78 \%)$ for poly $(\varepsilon \mathrm{CL})$ functionalized by $1,2,3$, and 4 , respectively. ${ }^{1} \mathrm{H} \mathrm{NMR}\left(\mathrm{CDCl}_{3}, 20{ }^{\circ} \mathrm{C}\right) \delta$ : $7.31\left(\mathrm{~m}, 5 \mathrm{H}, \mathrm{C}_{6} \mathrm{H}_{5}\right) ; 5.07\left(\mathrm{~s}, 2 \mathrm{H}, \mathrm{PhCH}_{2}\right) ; 4.02\left(\mathrm{t}, 299 \mathrm{H},-\mathrm{OCH}_{2}-\right.$ of poly $\left.(\varepsilon \mathrm{CL})\right) ; 2.81(\mathrm{~s}, 4 \mathrm{H}$, $-\mathrm{CH}_{2}-$ of NHS); $2.67\left(\mathrm{t},{ }^{3} \mathrm{~J}=7.5 \mathrm{~Hz}, 2 \mathrm{H} ;-\mathrm{CH}_{2} \mathrm{CH}_{2} \mathrm{CH}_{2} \mathrm{C}(\mathrm{O}) \mathrm{NHS}\right) ; 2.42\left(\mathrm{t},{ }^{3} \mathrm{~J}=7.5 \mathrm{~Hz}\right.$, $\left.2 \mathrm{H} ;-\mathrm{CH}_{2} \mathrm{CH}_{2} \mathrm{CH}_{2} \mathrm{C}(\mathrm{O}) \mathrm{NHS}\right) ; 2.27\left(\mathrm{t}, 296 \mathrm{H}, \mathrm{C}(\mathrm{O}) \mathrm{CH}_{2}\right.$ of poly $(\varepsilon \mathrm{CL})$ ); $2.02\left(\mathrm{p},{ }^{3} \mathrm{~J}=7.5 \mathrm{~Hz}\right.$, $\left.2 \mathrm{H} ;-\mathrm{CH}_{2} \mathrm{CH}_{2} \mathrm{CH}_{2} \mathrm{C}(\mathrm{O}) \mathrm{NHS}\right) ; 1.61\left(\mathrm{~m}, 603 \mathrm{H},-\mathrm{CH}_{2}-\right.$ of poly $\left.(\varepsilon \mathrm{CL})\right) ; 1.34\left(\mathrm{p}, 302 \mathrm{H},-\mathrm{CH}_{2}-\right.$ of poly $(\varepsilon \mathrm{CL}))(\operatorname{poly}(\varepsilon \mathrm{CL})-1) ; \delta: 7.34\left(\mathrm{~m}, 5 \mathrm{H}, \mathrm{C}_{6} \mathrm{H}_{5}\right) ; 5.10\left(\mathrm{~s}, 2 \mathrm{H}, \mathrm{PhCH}_{2}\right) ; 4.61(\mathrm{~s}, 0.63 \mathrm{H}$, $\left.-\mathrm{OCH}_{2} \mathrm{C}(\mathrm{O})-\right) ; 4.05\left(\mathrm{t}, 291 \mathrm{H},-\mathrm{OCH}_{2}-\right.$ of poly $(\varepsilon \mathrm{CL})$ ); $2.86\left(\mathrm{~s}, 1.54 \mathrm{H},-\mathrm{CH}_{2}-\right.$ of NHS); 2.29 $\left(\mathrm{t}, 291 \mathrm{H}, \mathrm{C}(\mathrm{O}) \mathrm{CH}_{2}\right.$ of $\left.\operatorname{poly}(\varepsilon \mathrm{CL})\right) ; 1.63\left(\mathrm{~m}, 592 \mathrm{H},-\mathrm{CH}_{2}-\right.$ of poly $\left.(\varepsilon \mathrm{CL})\right) ; 1.37\left(\mathrm{p}, 297 \mathrm{H},-\mathrm{CH}_{2}-\right.$ of $\operatorname{poly}(\varepsilon \mathrm{CL}))(\operatorname{poly}(\varepsilon \mathrm{CL})-2) ; \delta: 7.34\left(\mathrm{~m}, 5 \mathrm{H}, \mathrm{C}_{6} \mathrm{H}_{5}\right) ; 6.79(\mathrm{~s}, 0.79 \mathrm{H},-\mathrm{CH}=$ of MI); $5.10(\mathrm{~s}, 2 \mathrm{H}$, $\left.\mathrm{PhCH}_{2}\right) ; 4.61\left(\mathrm{~s}, 0.77 \mathrm{H},-\mathrm{NCH}_{2} \mathrm{C}(\mathrm{O})-\right) ; 4.04\left(\mathrm{t}, 298 \mathrm{H},-\mathrm{OCH}_{2}-\right.$ of poly $\left.(\varepsilon \mathrm{CL})\right) ; 2.29(\mathrm{t}, 297 \mathrm{H}$, $\mathrm{C}(\mathrm{O}) \mathrm{CH}_{2}$ of poly $\left.(\varepsilon \mathrm{CL})\right) ; 1.64\left(\mathrm{~m}, 600 \mathrm{H},-\mathrm{CH}_{2}-\right.$ of poly $\left.(\varepsilon \mathrm{CL})\right) ; 1.37\left(\mathrm{p}, \mathrm{Hz}, 303 \mathrm{H},-\mathrm{CH}_{2}-\right.$ of poly $(\varepsilon \mathrm{CL}))(\operatorname{poly}(\varepsilon \mathrm{CL})-3) ; \delta: 7.33\left(\mathrm{~m}, 5 \mathrm{H}, \mathrm{C}_{6} \mathrm{H}_{5}\right) ; 6.69\left(\mathrm{~s}, 1.51 \mathrm{H},-\mathrm{NCH}_{2} \mathrm{C}(\mathrm{O})-\right)$; 5.09 (s, 2H, $\left.\mathrm{PhCH}_{2}\right) ; 4.04\left(\mathrm{t}, 315 \mathrm{H},-\mathrm{OCH}_{2}-\right.$ of poly $\left.(\varepsilon \mathrm{CL})\right) ; 3.80\left(\mathrm{t},{ }^{3} \mathrm{~J}=7.1 \mathrm{~Hz}, 1.51 \mathrm{H},-\mathrm{NCH}_{2} \mathrm{CH}_{2} \mathrm{C}(\mathrm{O})-\right)$; $2.61\left(\mathrm{t},{ }^{3} \mathrm{~J}=7.1 \mathrm{~Hz}, 1.49 \mathrm{H},-\mathrm{NCH}_{2} \mathrm{CH}_{2} \mathrm{C}(\mathrm{O})-\right) ; 2.28\left(\mathrm{t}, 314 \mathrm{H}, \mathrm{C}(\mathrm{O}) \mathrm{CH}_{2}\right.$ of poly $\left.(\varepsilon \mathrm{CL})\right) ; 1.62$ $\left(\mathrm{m}, 634 \mathrm{H},-\mathrm{CH}_{2}-\right.$ of $\left.\operatorname{poly}(\varepsilon \mathrm{CL})\right) ; 1.35\left(\mathrm{p}, 314 \mathrm{H},-\mathrm{CH}_{2}-\right.$ of $\left.\operatorname{poly}(\varepsilon \mathrm{CL})\right)(\operatorname{poly}(\varepsilon \mathrm{CL})-4) .{ }^{1} \mathrm{H}$ NMR spectra are presented in Figures S12-S15 in the Supplementary Materials.

\subsubsection{Polymerization of L-LA with Termination by $\mathbf{1}$ and $\mathbf{4}$}

A preheated $30 \mathrm{~mL}$ glass ampoule was equipped with a magnetic stir bar and a septum and then filled with dry argon. L-LA (3.00 g, $20.8 \mathrm{mmol}, 120 \mathrm{eq}$.) was placed into the ampule, THF was added to total volume of $8.4 \mathrm{~mL}$. The mixture was placed in ice bath, BHT-Mg (73 mg, $0.17 \mathrm{mmol} \mathrm{Mg,} 1$ eq.) in THF solvent $(2.0 \mathrm{~mL}$ ) was added (resulting concentration of 
L-LA was $2 \mathrm{M})$. After $1 \mathrm{~h}$ of stirring, acyl chloride 1 or 4 ( $0.69 \mathrm{mmol}, 4$ eq.) in $\mathrm{CH}_{2} \mathrm{Cl}_{2}$ solvent $(2 \mathrm{~mL})$ was added. The mixture was allowed to warm to RT and stirred for $8 \mathrm{~h}$. Reaction mixture was evaporated with $\mathrm{CH}_{2} \mathrm{Cl}_{2}$ twice for THF removing. The residue was dissolved in $\mathrm{CH}_{2} \mathrm{Cl}_{2}(40 \mathrm{~mL})$, washed by $0.7 \mathrm{M}$ aq. $\mathrm{HCl}$, by water, dried over $\mathrm{MgSO}_{4}$ and filtered. The filtrate was evaporated to residual volume of $20 \mathrm{~mL}$ and poured into $\mathrm{Et}_{2} \mathrm{O}(100 \mathrm{~mL})$. The polymer was filtered off, dried at $20{ }^{\circ} \mathrm{C}$ and 0.01 Torr. The yields were $2.82(94 \%)$ and $2.94 \mathrm{~g}(98 \%)$ for poly(L-LA) functionalized by 1 and 4 , respectively. ${ }^{1} \mathrm{H} \mathrm{NMR}\left(\mathrm{CDCl}_{3}\right.$, $\left.20{ }^{\circ} \mathrm{C}\right) \delta: 7.35\left(\mathrm{~m}, 5 \mathrm{H}, \mathrm{C}_{6} \mathrm{H}_{5}\right) ; 5.16\left(\mathrm{q},{ }^{3} \mathrm{~J}=7.1 \mathrm{~Hz}, 257 \mathrm{H},-\mathrm{OCH}\left(\mathrm{CH}_{3}\right)-\right.$ of poly $\left.(\mathrm{L}-\mathrm{LA})\right) ; 2.83$ (s, $4 \mathrm{H},-\mathrm{CH}_{2}-$ of NHS); $2.73\left(\mathrm{t},{ }^{3} \mathrm{~J}=7.5 \mathrm{~Hz}, 2 \mathrm{H} ;-\mathrm{CH}_{2} \mathrm{CH}_{2} \mathrm{CH}_{2} \mathrm{C}(\mathrm{O}) \mathrm{NHS}\right) ; 2.55\left(\mathrm{t},{ }^{3} \mathrm{~J}=7.5 \mathrm{~Hz}\right.$, $2 \mathrm{H} ;-\mathrm{CH}_{2} \mathrm{CH}_{2} \mathrm{CH}_{2} \mathrm{C}(\mathrm{O}) \mathrm{NHS}$ ); 2.09 (p, $\left.{ }^{3} \mathrm{~J}=7.5 \mathrm{~Hz}, 2 \mathrm{H} ;-\mathrm{CH}_{2} \mathrm{CH}_{2} \mathrm{CH}_{2} \mathrm{C}(\mathrm{O}) \mathrm{NHS}\right) ; 1.58$ $\left(\mathrm{d},{ }^{3} \mathrm{~J}=7.1 \mathrm{~Hz}, 771 \mathrm{H},-\mathrm{CH}_{2}-\right.$ of poly(L-LA)) (poly(L-LA)-1); $\delta: 7.34\left(\mathrm{~m}, 5 \mathrm{H}, \mathrm{C}_{6} \mathrm{H}_{5}\right) ; 6.69$ $\left(\mathrm{s}, 2 \mathrm{H},-\mathrm{NCH}_{2} \mathrm{C}(\mathrm{O})-\right) ; 5.16\left(\mathrm{q}, 312 \mathrm{H},-\mathrm{OCH}\left(\mathrm{CH}_{3}\right)-\right.$ of poly $\left.(\mathrm{L}-\mathrm{LA})\right) ; 3.84\left(\mathrm{t},{ }^{3} \mathrm{~J}=7.1 \mathrm{~Hz}, 2 \mathrm{H}\right.$, $\left.-\mathrm{NCH}_{2} \mathrm{CH}_{2} \mathrm{C}(\mathrm{O})-\right) ; 2.74\left(\mathrm{t},{ }^{3} \mathrm{~J}=7.1 \mathrm{~Hz}, 2 \mathrm{H},-\mathrm{NCH}_{2} \mathrm{CH}_{2} \mathrm{C}(\mathrm{O})-\right) ; 1.58\left(\mathrm{~d}, 975 \mathrm{H},-\mathrm{CH}_{2}-\right.$ of poly(L-LA)) (poly(L-LA)-4). ${ }^{1} \mathrm{H}$ NMR spectra are presented in Figures S16 and S17 in the Supplementary Materials.

\subsubsection{Polymerization of EtEP with Termination by $\mathbf{1}$ and 4}

A preheated $30 \mathrm{~mL}$ glass ampoule was equipped with a magnetic stir bar and a septum and then filled with dry argon. EtEP (2.83 g, $20.8 \mathrm{mmol}, 120$ eq.) was placed into the ampule, $\mathrm{CH}_{2} \mathrm{Cl}_{2}$ was added to total volume of $8.4 \mathrm{~mL}$. The mixture was placed in ice bath, cooled to $5^{\circ} \mathrm{C}$, BHT-Mg (73 mg, $0.17 \mathrm{mmol} \mathrm{Mg}, 1$ eq. $)$ in solvent THF (2.0 mL) was added (resulting concentration of EtEP was $2 \mathrm{M}$ ). After $1 \mathrm{~h}$ of stirring, acyl chloride 1 or 4 ( $0.69 \mathrm{mmol}, 4$ eq.) in $\mathrm{CH}_{2} \mathrm{Cl}_{2}$ solvent $(2 \mathrm{~mL})$ was added. The mixture was allowed to warm to RT and stirred for $4 \mathrm{~h}$. Reaction mixture was precipitated into diethyl ether $(100 \mathrm{~mL})$ and centrifuged. The residue was dissolved in dry DMSO $(8 \mathrm{~mL})$ and precipitated into DMM (50 mL). The polymer was separated by decantation centrifugation and dried at $20^{\circ} \mathrm{C}$ and 0.01 Torr. The yields were 1.50 (54\%) and $1.65 \mathrm{~g} \mathrm{(59 \% )} \mathrm{for}$ poly(EtEP) functionalized by 1 and 4, respectively. ${ }^{1} \mathrm{H} \mathrm{NMR}\left(\mathrm{CDCl}_{3}, 20{ }^{\circ} \mathrm{C}\right) \delta: 7.35(\mathrm{~m}$, $\left.5 \mathrm{H}, \mathrm{C}_{6} \mathrm{H}_{5}\right) ; 5.05\left(\mathrm{~d},{ }^{3} \mathrm{~J}_{\mathrm{HP}}=9.0 \mathrm{~Hz}, 2 \mathrm{H}, \mathrm{PhCH}_{2}\right) ; 4.3-4.1\left(\mathrm{~m}, 491 \mathrm{H},-\mathrm{O}\left(\mathrm{CH}_{2}\right)_{2} \mathrm{O}-\right) ; 2.82(\mathrm{~s}$, $4 \mathrm{H},-\mathrm{CH}_{2}-$ of NHS); $2.69\left(\mathrm{t},{ }^{3} \mathrm{~J}=7.4 \mathrm{~Hz}, 2 \mathrm{H} ;-\mathrm{CH}_{2} \mathrm{CH}_{2} \mathrm{CH}_{2} \mathrm{C}(\mathrm{O}) \mathrm{NHS}\right) ; 2.48\left(\mathrm{t},{ }^{3} \mathrm{~J}=7.3 \mathrm{~Hz}\right.$, $2 \mathrm{H} ;-\mathrm{CH}_{2} \mathrm{CH}_{2} \mathrm{CH}_{2} \mathrm{C}(\mathrm{O}) \mathrm{NHS}$ ); 2.03 (p, $\left.{ }^{3} \mathrm{~J}=7.3 \mathrm{~Hz}, 2 \mathrm{H} ;-\mathrm{CH}_{2} \mathrm{CH}_{2} \mathrm{CH}_{2} \mathrm{C}(\mathrm{O}) \mathrm{NHS}\right) ; 1.81$ (m, $\left.237 \mathrm{H},-\mathrm{PCH}_{2} \mathrm{CH}_{3}\right) ; 1.15\left(\mathrm{dt}^{3} \mathrm{~J}=7.6 \mathrm{~Hz},{ }^{4} J_{\mathrm{HP}}=20.5 \mathrm{~Hz}, 360 \mathrm{H},-\mathrm{PCH}_{2} \mathrm{CH}_{3}\right)$ (poly(EtEP)1); $\delta: 7.36\left(\mathrm{~m}, 5 \mathrm{H}, \mathrm{C}_{6} \mathrm{H}_{5}\right) ; 6.71\left(\mathrm{~s}, 2 \mathrm{H},-\mathrm{NCH}_{2} \mathrm{C}(\mathrm{O})-\right) ; 5.06\left(\mathrm{~d}, 2 \mathrm{H}, \mathrm{PhCH}_{2}\right) ; 4.3-4.1$ (m, $\left.521 \mathrm{H},-\mathrm{O}\left(\mathrm{CH}_{2}\right)_{2} \mathrm{O}-\right) ; 3.82\left(\mathrm{t},{ }^{3} \mathrm{~J}=7.1 \mathrm{~Hz}, 2 \mathrm{H},-\mathrm{NCH}_{2} \mathrm{CH}_{2} \mathrm{C}(\mathrm{O})-\right) ; 2.66\left(\mathrm{t},{ }^{3} \mathrm{~J}=7.1 \mathrm{~Hz}, 2 \mathrm{H}\right.$, $\left.-\mathrm{NCH}_{2} \mathrm{CH}_{2} \mathrm{C}(\mathrm{O})-\right) ; 1.80\left(\mathrm{~m}, 237 \mathrm{H},-\mathrm{PCH}_{2} \mathrm{CH}_{3}\right) ; 1.16\left(\mathrm{dt}, 360 \mathrm{H},-\mathrm{PCH}_{2} \mathrm{CH}_{3}\right)$ (poly(EtEP)-4). ${ }^{31} \mathrm{P} \mathrm{NMR}\left(\mathrm{CDCl}_{3}, 20{ }^{\circ} \mathrm{C}\right) \delta: 35.3(\mathrm{~s}) .{ }^{1} \mathrm{H}$ NMR spectra are presented in Figures S18 and S19 in the Supplementary Materials.

\subsubsection{Synthesis of $\varepsilon$ CL/EtEP Block Copolymers with Termination by $\mathbf{1}$ and $\mathbf{4}$}

A preheated $30 \mathrm{~mL}$ glass ampoule was equipped with a magnetic stir bar and a septum and then with dry argon. $\varepsilon C L(2.30 \mathrm{~mL}, 2.37 \mathrm{~g}, 20.8 \mathrm{mmol}, 120$ eq.) was placed into the ampule, $\mathrm{CH}_{2} \mathrm{Cl}_{2}$ was added to total volume of $8.4 \mathrm{~mL}$. The mixture was cooled to $5{ }^{\circ} \mathrm{C}$, BHT-Mg (73 mg, $0.17 \mathrm{mmol} \mathrm{Mg,} 1$ eq.) in solvent THF $(2.0 \mathrm{~mL}$ ) was added (resulting concentration of $\varepsilon C L$ was $2 \mathrm{M})$. After $4 \mathrm{~h}$ of stirring, EtEP $(826 \mathrm{mg}, 6.1 \mathrm{mmol}, 35 \mathrm{eq}$.) was added. After $8 \mathrm{~h}$ of stirring, acyl chloride 1 or 4 (0.69 mmol, 4 eq.) in $\mathrm{CH}_{2} \mathrm{Cl}_{2}$ solvent $(2 \mathrm{~mL})$ was added. The mixture was allowed to warm to RT and stirred for $4 \mathrm{~h}$. Reaction mixture was evaporated twice with $\mathrm{CH}_{2} \mathrm{Cl}_{2}$ for removal of THF. The residue was dissolved in $\mathrm{CH}_{2} \mathrm{Cl}_{2}(40 \mathrm{~mL})$, washed by $0.7 \mathrm{M}$ aq. $\mathrm{HCl}$, by water, dried over $\mathrm{MgSO}_{4}$ and filtered. The filtrate was evaporated to residual volume of $20 \mathrm{~mL}$ and poured into $\mathrm{Et}_{2} \mathrm{O}(100 \mathrm{~mL})$. The polymer was filtered off, dried at $20^{\circ} \mathrm{C}$ and 0.01 Torr. The yields were $1.99(62 \%)$ and $2.25 \mathrm{~g}$ (70\%) for copolymers functionalized by 1 and 4, respectively. ${ }^{1} \mathrm{H} \mathrm{NMR}\left(\mathrm{CDCl}_{3}, 20{ }^{\circ} \mathrm{C}\right)$ $\delta: 7.34\left(\mathrm{~m}, 5 \mathrm{H}, \mathrm{C}_{6} \mathrm{H}_{5}\right) ; 5.10\left(\mathrm{~s}, 2 \mathrm{H}, \mathrm{PhCH}_{2}\right) ; 4.3-4.1\left(\mathrm{~m}, 53 \mathrm{H},-\mathrm{O}\left(\mathrm{CH}_{2}\right)_{2} \mathrm{O}-\right) ; 4.04(\mathrm{t}, 262 \mathrm{H}$, $-\mathrm{OCH}_{2}-$ of poly $\left.(\varepsilon \mathrm{CL})\right) ; 2.83\left(\mathrm{~s}, 4 \mathrm{H},-\mathrm{CH}_{2}-\right.$ of $\left.\mathrm{NHS}\right) ; 2.71\left(\mathrm{t}, 2 \mathrm{H} ;-\mathrm{CH}_{2} \mathrm{CH}_{2} \mathrm{CH}_{2} \mathrm{C}(\mathrm{O}) \mathrm{NHS}\right)$; $2.51\left(\mathrm{t}, 2 \mathrm{H} ;-\mathrm{CH}_{2} \mathrm{CH}_{2} \mathrm{CH}_{2} \mathrm{C}(\mathrm{O}) \mathrm{NHS}\right) ; 2.29$ (t, 259H, $\mathrm{C}(\mathrm{O}) \mathrm{CH}_{2}$ of poly $(\varepsilon \mathrm{CL})$ ); 2.07 (p, 2H; 
$\left.-\mathrm{CH}_{2} \mathrm{CH}_{2} \mathrm{CH}_{2} \mathrm{C}(\mathrm{O}) \mathrm{NHS}\right) ; 1.80\left(\mathrm{~m}, 27 \mathrm{H},-\mathrm{PCH}_{2} \mathrm{CH}_{3}\right) ; 1.63\left(\mathrm{~m}, 528 \mathrm{H},-\mathrm{CH}_{2}-\right.$ of poly $(\varepsilon \mathrm{CL})$ ); $1.36\left(\mathrm{p}, 265 \mathrm{H},-\mathrm{CH}_{2}-\right.$ of poly $(\varepsilon \mathrm{CL}) ; 1.16\left(\mathrm{dt}, 43 \mathrm{H},-\mathrm{PCH}_{2} \mathrm{CH}_{3}\right)$ (poly $(\varepsilon \mathrm{CL})-b$-poly $\left.(\mathrm{EtEP})-\mathbf{1}\right)$;

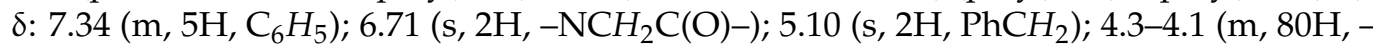
$\left.\mathrm{O}\left(\mathrm{CH}_{2}\right)_{2} \mathrm{O}-\right) ; 4.05\left(\mathrm{t}, 346 \mathrm{H},-\mathrm{OCH} \mathrm{H}_{2}-\right.$ of poly $\left.(\varepsilon \mathrm{CL})\right) ; 3.83\left(\mathrm{t}, 2 \mathrm{H},-\mathrm{NCH}_{2} \mathrm{CH}_{2} \mathrm{C}(\mathrm{O})-\right) ; 2.67(\mathrm{t}, 2 \mathrm{H}$, $\left.-\mathrm{NCH}_{2} \mathrm{CH}_{2} \mathrm{C}(\mathrm{O})-\right) ; 2.29\left(\mathrm{t}, \mathrm{Hz}, 344 \mathrm{H}, \mathrm{C}(\mathrm{O}) \mathrm{CH}_{2}\right.$ of poly $\left.(\varepsilon \mathrm{CL})\right) ; 1.80\left(\mathrm{~m}, 44 \mathrm{H},-\mathrm{PCH}_{2} \mathrm{CH}_{3}\right)$; $1.64\left(\mathrm{~m}, 698 \mathrm{H},-\mathrm{CH}_{2}-\right.$ of poly $\left.(\varepsilon \mathrm{CL})\right) ; 1.35\left(\mathrm{p}, 348 \mathrm{H},-\mathrm{CH}_{2}-\right.$ of poly $(\varepsilon \mathrm{CL}) ; 1.16(\mathrm{dt}, 62 \mathrm{H}$, $\left.-\mathrm{PCH}_{2} \mathrm{CH}_{3}\right)$ ) (poly( $(\varepsilon \mathrm{CL})-b$-poly(EtEP)-4). ${ }^{31} \mathrm{P} \mathrm{NMR}\left(\mathrm{CDCl}_{3}, 20{ }^{\circ} \mathrm{C}\right) \delta: 35.3$ (s). ${ }^{1} \mathrm{H} \mathrm{NMR}$ spectra are presented in Figures S20 and S21 in the Supplementary Materials.

\subsubsection{Polymerization of EtOEP with Termination by 1, BHT-Mg Catalyst}

A preheated $30 \mathrm{~mL}$ glass ampoule was equipped with a magnetic stir bar and a septum and then filled with dry argon. EtOEP (3.16 g, $20.8 \mathrm{mmol}, 120$ eq.) was placed into the ampule, $\mathrm{CH}_{2} \mathrm{Cl}_{2}$ was added to total volume of $8.4 \mathrm{~mL}$. The mixture was placed in ice bath, cooled to $5^{\circ} \mathrm{C}$, BHT-Mg (73 mg, $0.17 \mathrm{mmol} \mathrm{Mg}$, 1 eq.) in THF solvent $(2.0 \mathrm{~mL})$ was added (resulting concentration of EtOEP was $2 \mathrm{M}$ ). After $10 \mathrm{~min}$ of stirring, acyl chloride 1 (0.69 mmol, 4 eq.) in $\mathrm{CH}_{2} \mathrm{Cl}_{2}$ solvent $(2 \mathrm{~mL})$ was added. The mixture was allowed to warm to RT and stirred for $8 \mathrm{~h}$. The reaction mixture was evaporated twice with $\mathrm{CH}_{2} \mathrm{Cl}_{2}$ for removal of THF. The residue was dissolved in $\mathrm{CH}_{2} \mathrm{Cl}_{2}(10 \mathrm{~mL})$, precipitated into diethyl ether $(80 \mathrm{~mL})$. The sediment was dissolved in dry DMSO $(10 \mathrm{~mL})$ and precipitated into DMM $(80 \mathrm{~mL})$. The polymer was separated by centrifugation and dried at $20{ }^{\circ} \mathrm{C}$ and 0.01 Torr. The yield was $2.28 \mathrm{~g}(72 \%) .{ }^{1} \mathrm{H}$ NMR $\left(\mathrm{CDCl}_{3}, 20{ }^{\circ} \mathrm{C}\right) \delta: 7.37\left(\mathrm{~m}, 5 \mathrm{H}, \mathrm{C}_{6} \mathrm{H}_{5}\right) ; 5.07$ $\left(\mathrm{d},{ }^{3} \mathrm{~J}_{\mathrm{HP}}=8.2 \mathrm{~Hz}, 2 \mathrm{H}, \mathrm{PhCH}_{2}\right) ; 4.25\left(\mathrm{~m},-\mathrm{O}\left(\mathrm{CH}_{2}\right)_{2} \mathrm{O}-\right) ; 4.15\left(\mathrm{~m},-\mathrm{OCH}_{2} \mathrm{CH}_{3}\right)\{894 \mathrm{H}\} ; 2.83$ $\left(\mathrm{s}, 4 \mathrm{H},-\mathrm{CH}_{2}-\right.$ of NHS); $2.71\left(\mathrm{t},{ }^{3} \mathrm{~J}=7.1 \mathrm{~Hz}, 2 \mathrm{H} ;-\mathrm{CH}_{2} \mathrm{CH}_{2} \mathrm{CH}_{2} \mathrm{C}(\mathrm{O}) \mathrm{NHS}\right) ; 2.44\left(\mathrm{t},{ }^{3} \mathrm{~J}=7.2 \mathrm{~Hz}\right.$, $2 \mathrm{H}$; $-\mathrm{CH}_{2} \mathrm{CH}_{2} \mathrm{CH}_{2} \mathrm{C}(\mathrm{O}) \mathrm{NHS}$ ); 2.05 (p, ${ }^{3} \mathrm{~J}=7.2 \mathrm{~Hz}, 2 \mathrm{H} ;-\mathrm{CH}_{2} \mathrm{CH}_{2} \mathrm{CH}_{2} \mathrm{C}(\mathrm{O}) \mathrm{NHS}$ ); 1.34 $\left(\mathrm{td},{ }^{3} \mathrm{~J}=6.9 \mathrm{~Hz},{ }^{5} \mathrm{HP}_{\mathrm{HP}}=1.1 \mathrm{~Hz}, 437 \mathrm{H},-\mathrm{OCH}_{2} \mathrm{CH}_{3}\right) .{ }^{31} \mathrm{P} \mathrm{NMR}\left(\mathrm{CDCl}_{3}, 20{ }^{\circ} \mathrm{C}\right) \delta:-1.20(\mathrm{~s}) .{ }^{1} \mathrm{H}$ NMR spectrum of poly(EtOEP)-1 is presented in Figure S22 in the Supplementary Materials.

\subsubsection{Polymerization of EtOEP with Termination by $1, \mathrm{TBD} / \mathrm{BnOH}$ Catalyst}

A preheated $20 \mathrm{~mL}$ glass ampoule was equipped with a magnetic stir bar and a septum and then filled with dry argon. EtOEP $(1.52 \mathrm{~g}, 10 \mathrm{mmol}, 50 \mathrm{eq}$.) was placed into the ampule, $\mathrm{CH}_{2} \mathrm{Cl}_{2}$ was added to total volume of $3 \mathrm{~mL}$. The catalyst solution was prepared in $5 \mathrm{~mL}$ glass vial by addition of $\mathrm{BnOH}(22 \mathrm{mg}, 0.2 \mathrm{mmol})$ and TBD $(28 \mathrm{mg}, 0.2 \mathrm{mmol})$ to $\mathrm{CH}_{2} \mathrm{Cl}_{2}(1 \mathrm{~mL})$. The first solution was cooled to $5^{\circ} \mathrm{C}$, the catalyst solution was injected by a syringe, and $\mathrm{CH}_{2} \mathrm{Cl}_{2}$ was added to total volume of $5 \mathrm{~mL}$ ( $2 \mathrm{M}$ concentration of EtOEP). After 30 min of stirring, acyl chloride 1 (1.2 mmol, 6 eq.) in $\mathrm{CH}_{2} \mathrm{Cl}_{2}$ solvent $(1 \mathrm{~mL})$ was added. The mixture was allowed to warm to RT and stirred for $8 \mathrm{~h}$. The reaction mixture was evaporated to residual volume of $3 \mathrm{~mL}$, and precipitated into diethyl ether $(20 \mathrm{~mL})$. The residue was dried at $20{ }^{\circ} \mathrm{C}$ and 0.01 Torr. ${ }^{1} \mathrm{H}$ NMR spectrum is presented in Figure S23 in the Supplementary Materials.

\subsubsection{Reactions of $\operatorname{poly}(\varepsilon C L)$ and poly(EtOEP) with 1}

The samples of poly $(\varepsilon C L)$ and poly(EtOEP) were prepared by the methods described in Sections 2.3.3 and 2.3.7, respectively, polymerization was terminated by the addition of 5 eq. $\mathrm{AcOH}$. A total of $1 \mathrm{~g}$ of polymer was dissolved in $\mathrm{CH}_{2} \mathrm{Cl}_{2}(10 \mathrm{~mL})$, and acyl chloride $\mathbf{1}$ (6 eq.) was added. After $8 \mathrm{~h}$ of stirring, the solution was poured into $\mathrm{Et}_{2} \mathrm{O}(50 \mathrm{~mL})$, precipitated polymer was filtered off, dried in vacuo and analyzed using SEC and NMR spectroscopy. ${ }^{1} \mathrm{H}$ NMR spectra of the starting and NHS-functionalized poly $(\varepsilon C L)$ and poly $(E t O E P)$ are presented in Figures S24 and S25, respectively, in the Supplementary Materials.

\subsection{Reactions of NHS-Functionalized Polymers with ${ }^{i} \mathrm{BuNH}_{2}$}

\subsubsection{Reactions in $\mathrm{CH}_{2} \mathrm{Cl}_{2}$, Synthesis of poly( $(\varepsilon \mathrm{CL})-1-\mathrm{N}$ and poly(L-LA)-1-N}

According to previously reported procedure [65], NHS-functionalized polymer (200 mg) was dissolved in $\mathrm{CH}_{2} \mathrm{Cl}_{2}(2 \mathrm{~mL})$ and treated with ${ }^{\mathrm{i}} \mathrm{BuNH}_{2}$ (4 equivalents relative to amount of NHS groups in the polymer). After $6 \mathrm{~h}$ of stirring at $\mathrm{RT}, \mathrm{CH}_{2} \mathrm{Cl}_{2}(8 \mathrm{~mL})$ was 
added, organic phase was washed by $1 \mathrm{M}$ aq. $\mathrm{HCl}$, by water, dried over $\mathrm{MgSO}_{4}$ and filtered. The filtrate was evaporated to residual volume of $4 \mathrm{~mL}$, poured into $\mathrm{Et}_{2} \mathrm{O}(50 \mathrm{~mL})$, filtered off and dried at $20^{\circ} \mathrm{C}$ and 0.01 Torr. The yields were $120 \mathrm{mg}(60 \%)$ for poly $(\varepsilon \mathrm{CL})-1-\mathrm{N}$, $154 \mathrm{mg}(77 \%)$ for poly(L-LA)-1-N.

\subsubsection{Reactions in Aqueous Media, Synthesis of poly(EtEP)-1-N and poly(EtOEP)-1-N}

Taking into account previously reported procedures [66,67], NHS-functionalized polymer $(100 \mathrm{mg})$ was dissolved in water $(1 \mathrm{~mL})$ and treated with ${ }^{i} \mathrm{BuNH}_{2}$ (4 equivalents relative to amount of NHS groups in the polymer). After $6 \mathrm{~h}$ at RT, the reaction solution was dialyzed in distilled water using benzoylated cellulose dialysis membrane D2272 (MWCO 2000). The solution of the polymer was lyophilized, the residue was dissolved in $\mathrm{CH}_{2} \mathrm{Cl}_{2}$ $(2 \mathrm{~mL})$ and precipitated into DMM $(20 \mathrm{~mL})$. The polymer was separated by centrifugation and dried at $20^{\circ} \mathrm{C}$ and 0.01 Torr. The yields were $54 \mathrm{mg}(54 \%)$ for poly(EtEP)-1-N, $59 \mathrm{mg}$ (59\%) for poly(EtOEP)-1-N.

\subsubsection{NMR Data}

Poly $(\varepsilon \mathrm{CL})-1-\mathrm{N}:{ }^{1} \mathrm{H}$ NMR $\left(\mathrm{CDCl}_{3}, 20{ }^{\circ} \mathrm{C}\right) \delta: 7.34\left(\mathrm{~m}, 5 \mathrm{H}, \mathrm{C}_{6} \mathrm{H}_{5}\right) ; 5.10\left(\mathrm{~s}, 2 \mathrm{H}, \mathrm{PhCH}_{2}\right)$; $4.05\left(\mathrm{t}, 261 \mathrm{H},-\mathrm{OCH}_{2}-\right.$ of poly $\left.(\varepsilon \mathrm{CL})\right) ; 3.07\left(\mathrm{t}, 1.4 \mathrm{H},>\mathrm{NHCH}_{2} \mathrm{CH}<\right) ; 2.30\left(\mathrm{t}, 260 \mathrm{H}, \mathrm{C}(\mathrm{O}) \mathrm{CH}_{2}\right.$ of poly $(\varepsilon \mathrm{CL})) ; 2.23\left(\mathrm{t},{ }^{3} \mathrm{~J}=6.6 \mathrm{~Hz}, 1.5 \mathrm{H} ;-\mathrm{CH}_{2} \mathrm{CH}_{2} \mathrm{CH}_{2} \mathrm{C}(\mathrm{O}) \mathrm{NH}^{\mathrm{i}} \mathrm{Bu}\right) ; 1.64\left(\mathrm{~m}, 525 \mathrm{H},-\mathrm{CH}_{2}-\right.$ of poly $(\varepsilon \mathrm{CL})) ; 1.37\left(\mathrm{p}, 263 \mathrm{H},-\mathrm{CH}_{2}-\right.$ of poly $(\varepsilon \mathrm{CL}) ; 0.89\left(\mathrm{~d},{ }^{3} \mathrm{~J}=6.8 \mathrm{~Hz}, 4.5 \mathrm{H}, \mathrm{CH}\left(\mathrm{CH}_{3}\right)_{2}\right)$. See Figure S26 in the Supplementary Materials.

Poly(L-LA)-1-N: ${ }^{1} \mathrm{H}$ NMR $\left(\mathrm{CDCl}_{3}, 20^{\circ} \mathrm{C}\right) \delta: 7.34\left(\mathrm{~m}, 5 \mathrm{H}, \mathrm{C}_{6} \mathrm{H}_{5}\right) ; 6.03(\mathrm{bt}, 1 \mathrm{H},-\mathrm{NH}-) ; 5.15$ $\left(\mathrm{q}, 206 \mathrm{H},-\mathrm{OCH}\left(\mathrm{CH}_{3}\right)-\right) ; 3.06\left(\mathrm{t}, 2 \mathrm{H},>\mathrm{NHCH}_{2} \mathrm{CH}<\right) ; 2.44\left(\mathrm{~m}, 2 \mathrm{H},-\mathrm{CH}_{2} \mathrm{CH}_{2} \mathrm{CH}_{2} \mathrm{C}(\mathrm{O}) \mathrm{NH}^{\mathrm{i}} \mathrm{Bu}\right)$; $2.24\left(\mathrm{~m}, 2 \mathrm{H},-\mathrm{CH}_{2} \mathrm{CH}_{2} \mathrm{CH}_{2} \mathrm{C}(\mathrm{O}) \mathrm{NH}^{\mathrm{i}} \mathrm{Bu}\right) ; 2.01\left(\mathrm{p}, 2 \mathrm{H},-\mathrm{CH}_{2} \mathrm{CH}_{2} \mathrm{CH}_{2} \mathrm{C}(\mathrm{O}) \mathrm{NH}^{\mathrm{i}} \mathrm{Bu}\right) ; 1.57(\mathrm{~d}, 618 \mathrm{H}$, $\left.-\mathrm{OCH}\left(\mathrm{CH}_{3}\right)-\right) ; 0.90\left(\mathrm{~d}, 6 \mathrm{H}, \mathrm{CH}\left(\mathrm{CH}_{3}\right)_{2}\right)$. See Figure S27 in the Supplementary Materials.

Poly(EtEP)-1- $\mathrm{N}:{ }^{1} \mathrm{H}$ NMR $\left(\mathrm{CDCl}_{3}, 20^{\circ} \mathrm{C}\right) \delta: 7.35\left(\mathrm{~m}, 5 \mathrm{H}, \mathrm{C}_{6} \mathrm{H}_{5}\right) ; 5.06\left(\mathrm{~d}, 2 \mathrm{H}, \mathrm{PhCH}_{2}\right)$; 4.3-4.1 (m, 710H, $\left.-\mathrm{O}\left(\mathrm{CH}_{2}\right)_{2} \mathrm{O}-\right) ; 3.02\left(\mathrm{t}, 1.8 \mathrm{H},>\mathrm{NHCH}_{2} \mathrm{CH}<\right) ; 2.39\left(\mathrm{t}, 2 \mathrm{H},-\mathrm{CH}_{2} \mathrm{CH}_{2} \mathrm{CH}_{2} \mathrm{C}\right.$ $\left.(\mathrm{O}) \mathrm{NH}^{\mathrm{i}} \mathrm{Bu}\right) ; 2.24\left(\mathrm{t}, 2 \mathrm{H},-\mathrm{CH}_{2} \mathrm{CH}_{2} \mathrm{CH}_{2} \mathrm{C}(\mathrm{O}) \mathrm{NH}^{\mathrm{i}} \mathrm{Bu}\right) ; 1.94\left(\mathrm{p}, 2 \mathrm{H},-\mathrm{CH}_{2} \mathrm{CH}_{2} \mathrm{CH}_{2} \mathrm{C}(\mathrm{O}) \mathrm{NH}^{\mathrm{i}} \mathrm{Bu}\right)$; $1.80\left(\mathrm{~m}, 359 \mathrm{H},-\mathrm{PCH}_{2} \mathrm{CH}_{3}\right) ; 1.16\left(\mathrm{dt}, 537 \mathrm{H},-\mathrm{PCH}_{2} \mathrm{CH}_{3}\right) .{ }^{31} \mathrm{P} \mathrm{NMR}\left(\mathrm{CDCl}_{3}, 20{ }^{\circ} \mathrm{C}\right) \delta: 35.32$. See Figures S28 and S29 in the Supplementary Materials.

Poly(EtOEP)-1-N: ${ }^{1} \mathrm{H}$ NMR $\left(\mathrm{CDCl}_{3}, 20^{\circ} \mathrm{C}\right) \delta: 7.35\left(\mathrm{~m}, 5 \mathrm{H}, \mathrm{C}_{6} \mathrm{H}_{5}\right) ; 5.04\left(\mathrm{~d}, 2 \mathrm{H}, \mathrm{PhCH}_{2}\right)$; $4.21\left(\mathrm{~m},-\mathrm{O}\left(\mathrm{CH}_{2}\right)_{2} \mathrm{O}-\right) ; 4.12\left(\mathrm{~m},-\mathrm{OCH}_{2} \mathrm{CH}_{3}\right)\{934 \mathrm{H}\} ; 3.00\left(\mathrm{~d}\right.$ and d, $\left.0.8 \mathrm{H},>\mathrm{NCH}_{2} \mathrm{CH}<\right) ; 2.37(\mathrm{t}$, $\left.{ }^{3} \mathrm{~J}=6.6 \mathrm{~Hz}, 0.98 \mathrm{H} ;-\mathrm{CH}_{2} \mathrm{CH}_{2} \mathrm{CH}_{2} \mathrm{C}(\mathrm{O}) \mathrm{NH}^{\mathrm{i} B u}\right) ; 2.21\left(\mathrm{t},{ }^{3} \mathrm{~J}=6.6 \mathrm{~Hz}, 0.8 \mathrm{H} ;-\mathrm{CH}_{2} \mathrm{CH}_{2} \mathrm{CH}{ }_{2} \mathrm{C}(\mathrm{O})\right.$ $\left.\mathrm{NH}^{\mathrm{i}} \mathrm{Bu}\right) ; 1.93\left(\mathrm{p},{ }^{3} \mathrm{~J}=6.6 \mathrm{~Hz}, 0.8 \mathrm{H} ;-\mathrm{CH}_{2} \mathrm{CH}_{2} \mathrm{CH}_{2} \mathrm{C}(\mathrm{O}) \mathrm{NH}^{\mathrm{i} B u}\right) ; 1.71\left(\mathrm{~m}, 0.4 \mathrm{H},>\mathrm{NCH}_{2} \mathrm{CH}<\right)$; $1.31\left(\mathrm{td},{ }^{3} \mathrm{~J}=6.9 \mathrm{~Hz},{ }^{5} J_{\mathrm{HP}}=1.1 \mathrm{~Hz}, 458 \mathrm{H},-\mathrm{OCH}_{2} \mathrm{CH}_{3}\right) ; 0.85\left(\mathrm{~d},{ }^{3} \mathrm{~J}=6.8 \mathrm{~Hz}, 2.6 \mathrm{H}, \mathrm{CH}\left(\mathrm{CH}_{3}\right)_{2}\right)$. ${ }^{31} \mathrm{P}$ NMR $\left(\mathrm{CDCl}_{3}, 20{ }^{\circ} \mathrm{C}\right) \delta:-1.21$. See Figures $\mathrm{S} 30$ and $\mathrm{S} 31$ in the Supplementary Materials.

\subsection{Reactions of MI-Functionalized Polymers with $\mathrm{HSCH}_{2} \mathrm{COOMe}$}

\subsubsection{Reactions in Organic Solvent, Synthesis of poly( $(\mathrm{CL})-4-\mathrm{S}$ and poly(L-LA)-4-S}

According to previously reported procedure [68,69], MI-functionalized polymer (200 mg) was dissolved in $\mathrm{CH}_{2} \mathrm{Cl}_{2}(2 \mathrm{~mL})$ and treated with $\mathrm{HSCH}_{2} \mathrm{COOMe}$ and $\mathrm{Et}_{3} \mathrm{~N}(2$ and 4 eqs., respectively, relative to amount of MI groups in the polymer). After $6 \mathrm{~h}$ at RT, $\mathrm{CH}_{2} \mathrm{Cl}_{2}(8 \mathrm{~mL})$ was added, organic phase was washed by $1 \mathrm{M}$ aq. $\mathrm{HCl}$, by water, dried over $\mathrm{MgSO}_{4}$ and filtered. The filtrate was evaporated under reduced pressure to residual volume of $4 \mathrm{~mL}$ and poured into $\mathrm{Et}_{2} \mathrm{O}(50 \mathrm{~mL})$. The polymer was filtered off, dried at $20{ }^{\circ} \mathrm{C}$ and 0.01 Torr. The yields were $125 \mathrm{mg}(62 \%)$ for poly $(\varepsilon \mathrm{CL})-4-\mathrm{S}$ and $120 \mathrm{mg}(60 \%)$ for poly(L-LA)-4-S.

\subsubsection{Reaction in Aqueous Media, Synthesis of poly(EtEP)-4-S}

Analogous to the previously reported procedure [70], poly(EtEP)-4 (100 mg, $0.005 \mathrm{mmol}$ of MI groups) was dissolved in $\mathrm{H}_{2} \mathrm{O}(1 \mathrm{~mL})$ and treated with $\mathrm{HSCH}_{2} \mathrm{COOMe}(0.9 \mu \mathrm{L}, 2$ eq. $)$. After $6 \mathrm{~h}$ of stirring at RT, the reaction solution was dialyzed in distilled water using benzoylated cellulose dialysis membrane D2272 (MWCO 2000). The solution of the polymer was lyophilized, the residue was dissolved in $\mathrm{CH}_{2} \mathrm{Cl}_{2}(2 \mathrm{~mL})$ and precipitated into DMM 
(20 mL). The polymer was separated by centrifugation and dried at $20^{\circ} \mathrm{C}$ and 0.01 Torr. The yield was $69 \mathrm{mg}(69 \%)$.

\subsubsection{NMR Data}

Poly $(\varepsilon \mathrm{CL})-4-\mathrm{S}:{ }^{1} \mathrm{H}$ NMR $\left(\mathrm{CDCl}_{3}, 20{ }^{\circ} \mathrm{C}\right) \delta: 7.34\left(\mathrm{~m}, 5 \mathrm{H}, \mathrm{C}_{6} \mathrm{H}_{5}\right) ; 5.10$ (s, 2H, PhCH $)$; $4.04\left(\mathrm{t}, 241 \mathrm{H},-\mathrm{OCH}_{2}-\right.$ of $\left.\operatorname{poly}(\varepsilon \mathrm{CL})\right) ; 3.89 \& 3.37\left(\mathrm{~d}, \mathrm{~d},{ }^{2} \mathrm{~J}=15.8 \mathrm{~Hz}, 1.5 \mathrm{H},-\mathrm{SCH}_{2}-\right)$; $3.80\left(\mathrm{t},{ }^{3} \mathrm{~J}=7.1 \mathrm{~Hz}, 1.5 \mathrm{H},-\mathrm{NCH}_{2} \mathrm{CH}_{2} \mathrm{C}(\mathrm{O})-\right) ; 3.75\left(\mathrm{~s}, \sim 2 \mathrm{H},-\mathrm{SCH}_{3}\right) ; 3.15\left(\mathrm{dd},{ }^{2} \mathrm{~J}=18.9 \mathrm{~Hz}\right.$, $\left.{ }^{3} \mathrm{~J}=9.0 \mathrm{~Hz},-\mathrm{CH}(\mathrm{S}) \mathrm{CH}_{2}-\right) ; 2.60\left(\mathrm{t},{ }^{3} \mathrm{~J}=7.1 \mathrm{~Hz}, 1.5 \mathrm{H},-\mathrm{NCH}_{2} \mathrm{CH}_{2} \mathrm{C}(\mathrm{O})-\right) ; 2.51\left(\mathrm{dd},{ }^{2} \mathrm{~J}=18.9 \mathrm{~Hz}\right.$, $\left.{ }^{3} \mathrm{~J}=3.8 \mathrm{~Hz},-\mathrm{CH}(\mathrm{S}) \mathrm{CH}_{2}-\right) ; 2.30\left(\mathrm{t}, 242 \mathrm{H}, \mathrm{C}(\mathrm{O}) \mathrm{CH}_{2}\right.$ of poly $\left.(\varepsilon \mathrm{CL})\right) ; 1.64\left(\mathrm{~m}, 487 \mathrm{H},-\mathrm{CH}_{2}-\right.$ of $\operatorname{poly}(\varepsilon \mathrm{CL})) ; 1.37\left(\mathrm{p}, 241 \mathrm{H},-\mathrm{CH}_{2}-\right.$ of $\left.\operatorname{poly}(\varepsilon \mathrm{CL})\right)$.

Poly(L-LA)-4-S: ${ }^{1} \mathrm{H}$ NMR $\left(\mathrm{CDCl}_{3}, 20{ }^{\circ} \mathrm{C}\right) \delta: 7.35\left(\mathrm{~m}, 5 \mathrm{H}, \mathrm{C}_{6} \mathrm{H}_{5}\right) ; 5.15(\mathrm{q}, 275 \mathrm{H}$, $\left.-\mathrm{OCH}\left(\mathrm{CH}_{3}\right)-\right) ; 4.02\left(\mathrm{~m}, 1 \mathrm{H},-\mathrm{CH}_{2} \mathrm{CHS}-\right) ; 3.89$ (d, $\left.{ }^{2} \mathrm{~J}=15.0 \mathrm{~Hz}, 1 \mathrm{H},-\mathrm{SCH}_{2}-\right)$; $3.84(\mathrm{~m}, 2 \mathrm{H}$, $\left.-\mathrm{NCH}_{2} \mathrm{CH}_{2} \mathrm{C}(\mathrm{O})-\right) ; 3.76\left(\mathrm{~s}, 3 \mathrm{H},-\mathrm{OCH}_{3}\right) ; 3.37\left(\mathrm{~d},{ }^{2} \mathrm{~J}=15.0 \mathrm{~Hz}, 1 \mathrm{H},-\mathrm{SCH}_{2}-\right) ; 3.15(\mathrm{dd}, 1 \mathrm{H}$, $-\mathrm{CH}_{2} \mathrm{CHS}-$ ); 2.76 (m, 2H, $-\mathrm{NCH}_{2} \mathrm{CH}_{2} \mathrm{C}(\mathrm{O})-$ ); 2.49 (dd, $\left.1 \mathrm{H},-\mathrm{CH}_{2} \mathrm{CHS}-\right) ; 1.57$ (d, 832H, $\left.-\mathrm{OCH}\left(\mathrm{CH}_{3}\right)-\right)$.

Poly(EtEP)-4-S: ${ }^{1} \mathrm{H}$ NMR $\left(\mathrm{CDCl}_{3}, 20{ }^{\circ} \mathrm{C}\right) \delta: 7.36\left(\mathrm{~m}, 5 \mathrm{H}, \mathrm{C}_{6} \mathrm{H}_{5}\right) ; 5.06\left(\mathrm{~d}, 2 \mathrm{H}, \mathrm{PhCH}_{2}\right)$; 4.3-4.1 (m, 508H, -O(CH $\left.)_{2} \mathrm{O}-\right) ; 3.86\left(\mathrm{~d},{ }^{2} \mathrm{~J}=15.9 \mathrm{~Hz}, 1 \mathrm{H},-\mathrm{SCH}_{2}-\right) ; 3.80\left(\mathrm{t},{ }^{3} \mathrm{~J}=7.1 \mathrm{~Hz}, 2 \mathrm{H}\right.$, $\left.-\mathrm{NCH}_{2} \mathrm{CH}_{2} \mathrm{C}(\mathrm{O})-\right) ; 3.74\left(\mathrm{~s}, 3 \mathrm{H},-\mathrm{OCH}_{3}\right) ; 3.37\left(\mathrm{~d},{ }^{2} \mathrm{~J}=15.9 \mathrm{~Hz}, 1 \mathrm{H},-\mathrm{SCH}_{2}-\right) ; 2.65\left(\mathrm{t},{ }^{3} \mathrm{~J}=7.1 \mathrm{~Hz}\right.$, $\left.2 \mathrm{H},-\mathrm{NCH}_{2} \mathrm{CH}_{2} \mathrm{C}(\mathrm{O})-\right) ; 1.80\left(\mathrm{~m}, 250 \mathrm{H},-\mathrm{PCH}_{2} \mathrm{CH}_{3}\right) ; 1.16\left(\mathrm{dt}, 377 \mathrm{H},-\mathrm{PCH}_{2} \mathrm{CH}_{3}\right)$. ${ }^{31} \mathrm{P}$ NMR $\left(\mathrm{CDCl}_{3}, 20^{\circ} \mathrm{C}\right) \delta: 35.3(\mathrm{~s}) .{ }^{31} \mathrm{P} \mathrm{NMR}\left(\mathrm{CDCl}_{3}, 20^{\circ} \mathrm{C}\right) \delta: 35.25$.

\section{Results and Discussion}

\subsection{Functionalization of the Polymers by Termination of Living Polymerization}

The synthesis of the functionalized polymers by termination of "living" ROP was performed previously using both organocatalyst DBU $[37,44]$ and Al-based coordination catalyst $[45,46]$. However, degree of polymerization $\left(\mathrm{DP}_{\mathrm{n}}\right)$ in these experiments stood at 30-40, the polymers obtained were not considered as a base for functionalized polymer materials having required strength and plastic characteristics. We proposed that the synthesis of high molecular weight (MW) functionalized polymers can be based on the use of the complexes of more active metal than Al. Among the coordination catalysts available, derivatives on nontoxic metals $\mathrm{Al}, \mathrm{Zn}, \mathrm{Ca}$ and $\mathrm{Mg}$ [55,71,72], we chose the most active magnesium catalyst BHT-Mg (Scheme $2 b$ ) that had been previously used in ROP of lactones, lactides, cyclic phosphonates, and phosphates [47,49,50,52,54,73]. The choice of the magnesium catalyst was also due to high reactivity of magnesium alkoxides in reactions with acyl chlorides, demonstrated previously in the few publications [74,75].

Using BHT-Mg as a single-component catalyst, we studied living ROP of $\varepsilon$ CL, followed by the termination with different reagents. Addition of DSC to the reaction mixture resulted in a formation of NHS-substituted poly $(\varepsilon C L)$, however, degree of functionalization was only 33\% (Table 1, Entry 1 and Figure S9 in the Supplementary Materials). The addition of SA, followed by the reaction with N-hydroxysuccinimide/DCC, leads to the NHSsubstituted polymer with degree of functionalization of 51\% (Table 1, Entry 2 and Figure S10 in the Supplementary Materials).

We assumed that acyl chlorides could be more efficient reagents for the functionalization of polymers via termination of BHT-Mg catalyzed ROP. In the preliminary experiment, we polymerized L-LA in the presence of BHT-Mg at 80:1 L-LA/Mg ratio, and terminated the reaction by the addition of four equivalents of AcCl. Acetyl-terminated poly(L-LA) was isolated, degree of functionalization was 100\% (Figure S11 in the Supplementary Materials). Similar results had been obtained in AcCl-terminated ROP of $\varepsilon$ CL. When NHS-substituted acyl chloride $\mathbf{1}$ (Scheme 2b) [61] was used in $\mathbf{1} / \mathrm{Mg}$ ratio of 4:1, the near quantitative degree of the functionalization of poly $(\varepsilon C L)$ was achieved (Table 1, Entry 3 and Figure S12 in the Supplementary Materials).

In view of the results of these experiments, we proposed that termination of BHT-Mg catalyzed coordination ROP by functionalized acyl chlorides may be the most effective method for the obtaining of NHS- and MI-substituted polymers. In addition to 1, we 
synthesized NHS-derived acyl chloride 2 (new compound) and MI-derived acyl chlorides 3 [63] and 4 [64] (Scheme 2b). When 2 was used for the termination of $\varepsilon$ CL ROP, the degree of functionalization was 39\% (Table 1, Entry 4 and Figure S13 in the Supplementary Materials). Low reactivity of 2 may be due to the formation of $k^{2}$-chelate by carbonyl and ether oxygen atoms in $\mathbf{2}$ and BHT-Mg species.

MI-substituted acyl chlorides 3 and 4 demonstrated high reactivities, but the degrees of functionalization were far from quantitative in both cases (Figures S14 and S15 in the Supplementary Materials). The yield of MI-substituted polymer was substantially higher when 4 was used (Table 1, Entries 5 and 6). In the light of the results obtained, acyl chlorides 1 and $\mathbf{4}$ were selected for termination/functionalization of the ROP of other cyclic substrates.

When BHT-Mg catalyzed ROP of L-LA was terminated by acyl chlorides $\mathbf{1}$ and $\mathbf{4}$, the degrees of functionalization were found to be almost quantitative (Table 1, Entries 7 and 8 and Figure 1). The experiments with termination of the ROP of EtEP by 1 and 4 were also successful (Table 1, Entries 9 and 10, Figures S18 and S19 in the Supplementary Materials). In the synthesis of poly $(\varepsilon \mathrm{CL})-b$-poly(EtEP) copolymers termination of the "living" polymer chain by 1 and 4 resulted in the obtaining of exhaustively NHS- and MI-functionalized copolymers with expected comonomer ratios (Table 1, Entries 11 and 12, Figure 1). Termination of EtOEP ROP by 1 resulted in poly(EtOEP) with high degree of functionalization (Table 1, Entry 13 and Figure S22 in the Supplementary Materials).

In the final experiment (Table 1, Entry 14), we initiated polymerization of EtOEP by $\mathrm{TBD} / \mathrm{BnOH}$, and added 4 eq. of acyl chloride 1 after $30 \mathrm{~min}$ of the reaction. The obtained polymer had degree of the functionalization less than $50 \%$. Perhaps more significantly, ${ }^{1} \mathrm{H}$ NMR spectra of reprecipitated polymer mainly contained the signals of the side products with $\left(\mathrm{CH}_{2}\right)_{3} \mathrm{C}(\mathrm{O}) \mathrm{NHS}$ fragments (see Figure S23 in the Supplementary Materials), and SEC data pointed to partial fragmentation of the polymer. 
Table 1. Synthesis of NHS- and MI-functionalized polymers via termination of BHT-Mg catalyzed "living" ROP by DSC, SA and acyl chlorides $\mathbf{1 - 4}$.

\begin{tabular}{|c|c|c|c|c|c|c|c|c|c|c|c|}
\hline Entry & Mon1 & Mon2 & $\begin{array}{c}\text { ROP } \\
\text { Termination } \\
\text { Agent (TA) }\end{array}$ & $\begin{array}{c}\text { (Mon1)/(Mon2)/(Cat)/(TA) } \\
\text { Ratio }\end{array}$ & $\begin{array}{c}\text { Mon1 } 1 \\
\text { conv., } \% 1\end{array}$ & $\begin{array}{c}\text { Mon2 } \\
\text { conv., \% } 1\end{array}$ & $\begin{array}{c}M_{\mathrm{n}} \cdot 10^{3} \\
\text { (theor) }^{1}\end{array}$ & $\begin{array}{c}M_{\mathrm{n}} \cdot 10^{3} \\
(\mathrm{NMR})^{2}\end{array}$ & $\begin{array}{l}M_{n} \cdot 10^{3} \\
(\mathrm{SEC})^{3}\end{array}$ & $\begin{array}{c}\bigoplus_{\mathrm{M}} \\
(\mathrm{SEC})^{3}\end{array}$ & $\begin{array}{c}\text { Comp. of Polymer: } \\
\text { Mon1/Mon2/FG (NMR) }\end{array}$ \\
\hline 1 & $\varepsilon \mathrm{CL}$ & - & DSC & $50 /-/ 1 / 5$ & $>99$ & - & 5.96 & 6.0 & 6.4 & 1.19 & $50 /-/ 0.33$ \\
\hline 3 & $\varepsilon \mathrm{CL}$ & - & 1 & $120 /-/ 1 / 4$ & $>99$ & - & 14.02 & 17.3 & 16.1 & 1.18 & $149 /-/ 1.0$ \\
\hline 4 & $\varepsilon C L$ & - & 2 & $120 /-/ 1 / 4$ & $>99$ & - & 14.02 & 16.9 & 18.2 & 1.29 & $145 /-/ 0.39$ \\
\hline 5 & $\varepsilon \mathrm{CL}$ & - & 3 & $120 /-/ 1 / 4$ & $>99$ & - & 13.96 & 17.3 & 16.5 & 1.23 & $149 /-/ 0.40$ \\
\hline 6 & $\varepsilon C L$ & - & 4 & $120 /-/ 1 / 4$ & $>99$ & - & 13.94 & 18.2 & 22.4 & 1.15 & $157 /-/ 0.76$ \\
\hline 8 & L-LA & - & 4 & $120 /-/ 1 / 4$ & $>99$ & - & 17.56 & 22.8 & 25.6 & 1.55 & $156 /-/ 1.0$ \\
\hline 9 & EtEP & - & 1 & $120 /-/ 1 / 4$ & 94 & - & 15.67 & 17.1 & 14.3 & 1.19 & $123 /-/ 1.0$ \\
\hline 10 & EtEP & - & 4 & $120 /-/ 1 / 4$ & 95 & - & 15.78 & 17.9 & 14.5 & 1.18 & $130 /-/ 1.0$ \\
\hline 11 & $\varepsilon C L$ & EtEP & 1 & $120 / 35 / 1 / 4$ & $>99$ & 65 & 17.11 & 17.1 & 21.4 & 1.48 & $131 / 14 / 1.0$ \\
\hline 12 & $\varepsilon C L$ & EtEP & 4 & $120 / 35 / 1 / 4$ & $>99$ & 79 & 17.72 & 22.9 & 19.5 & 1.46 & $173 / 21 / 1.0$ \\
\hline 13 & EtOEP & - & 1 & $120 /-/ 1 / 4$ & 96 & - & 17.84 & 22.5 & 16.5 & 1.48 & $146 /-/ 1.0$ \\
\hline $14^{4}$ & EtOEP & - & 1 & $50 /-/ 1 / 4$ & $>99$ & - & 7.85 & 8.3 & 5.2 & 1.86 & $53 /-/<0.5$ \\
\hline
\end{tabular}

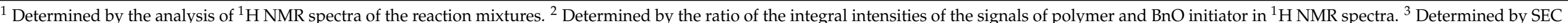

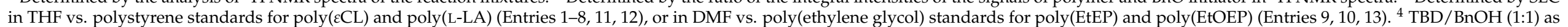
a catalyst. 

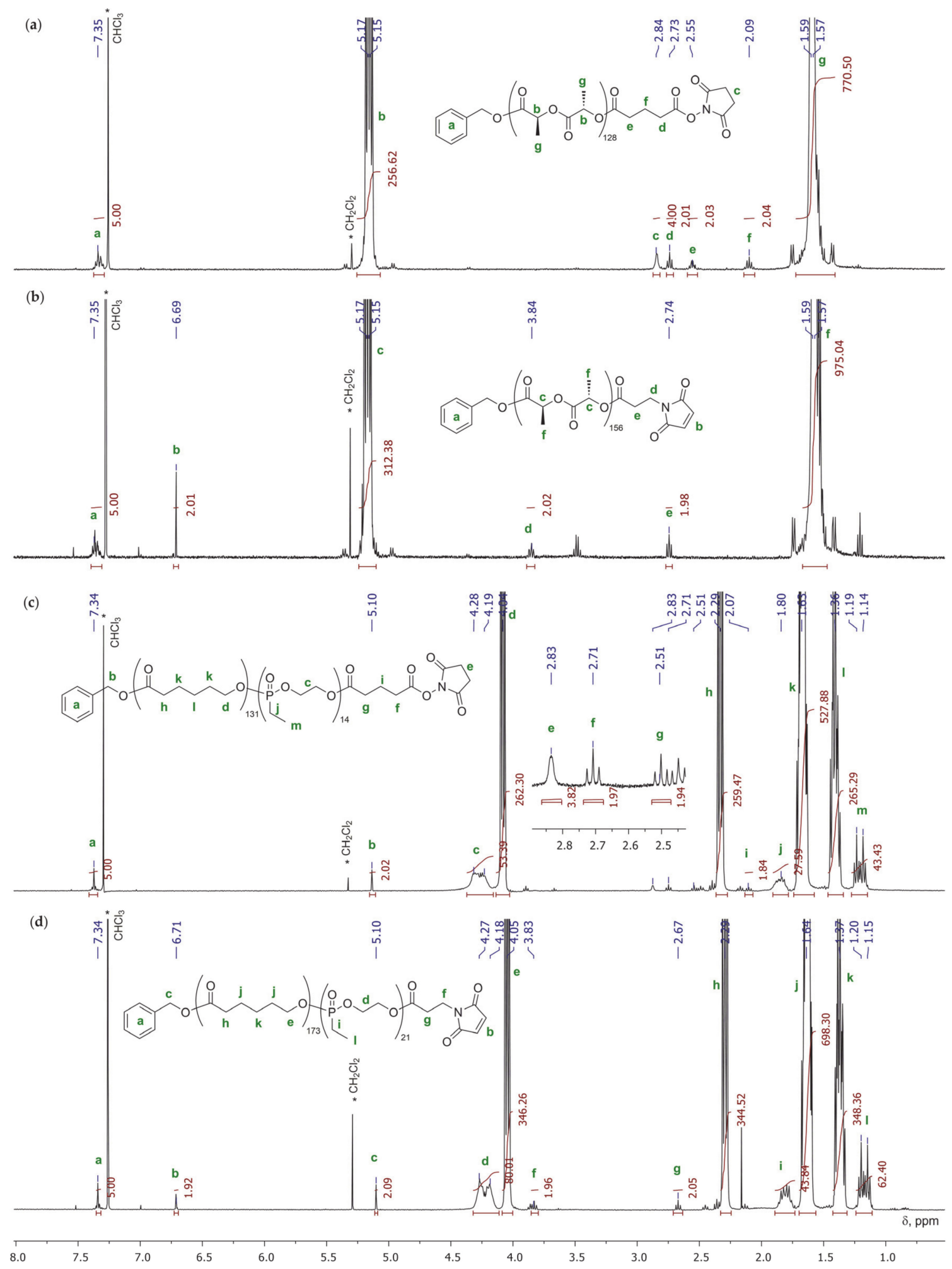

Figure 1. ${ }^{1} \mathrm{H}$ NMR spectra of NHS- and MI-functionalized polymers (Table 1, Entries 7 (a), 8 (b), 11 (c), and 12 (d)). The signals of the protons of the fragments of functionalized polymers are marked as letters (bold and green) the solvent impurities are marked by asterisks $\left(^{*}\right)$. 3.2. Functionalization by the Reaction of the Polymers with Acyl Chloride 1. 


\subsection{Functionalization by the Reaction of the Polymers with Acyl Chloride $\mathbf{1}$}

In this way, it is BHT-Mg catalyst that provides termination of the ROP of lactones, lactides, ethylene phosphonates, and ethylene phosphates by acyl chlorides with high degree of functionalization without the degradation of the polymer backbone.

The obvious alternative for the termination of "living" BHT-Mg catalyzed polymerization by acyl chlorides is a reaction of isolated polymers that contain -OH end groups with the same acyl chlorides. We synthesized the sample of poly $(\varepsilon C L)$ with degree of polymerization $\left(\mathrm{DP}_{\mathrm{n}}\right) \sim 125$, and carried out the reaction of this polymer with acyl chloride 1 in $\mathrm{CH}_{2} \mathrm{Cl}_{2}$. NHS-functionalized polymer was obtained (see Section 2.3.8), the ratio of $\mathrm{BnO}$ initiator group and NHS end group in this polymer was 1:0.76 (Figure S24 in the Supplementary Materials). As a result of the same experiment with poly(EtOEP) (DP $\sim 210$, see Section 2.3.8), the degree of functionalization was only 0.55 (Figure S25 in the Supplementary Materials). Thus, the two-stage approach, based on functionalization of -OH end groups of the separated polymers by acyl chlorides, was substantially inferior to the method, based on the reaction of the active polymeryl-Mg-BHT complex with acyl chlorides.

\subsection{Reactions of NHS-Functionalized Polymers with Amine-Containing Compounds}

The reactions of NHS-substituted organic compounds with amines are widely presented in the chemical literature, these reactions can be conducted under various conditions using both organic solvents and water media. Among known methods, we chose reactions in $\mathrm{CH}_{2} \mathrm{Cl}_{2}[65,69]$ and in water [66,67]. Other common solvents, DMF and DMSO, in our view, are less applicable for polymer modification owing to the complexity of the further removal of these solvents. In our experiments, we studied interaction of NHS-modified polymers, derivatives of $\mathbf{1}$, with ${ }^{\mathrm{i}} \mathrm{BuNH}_{2}$. The analysis of ${ }^{1} \mathrm{H}$ NMR spectra was performed with account of the characteristic signals of the starting NHS derivatives and isobutylamide fragment of the product (Scheme 3a). Degrees of functionalization were calculated from the ratios of the integral intensities of these characteristic signals and signals of $\mathrm{BnO}$ group.

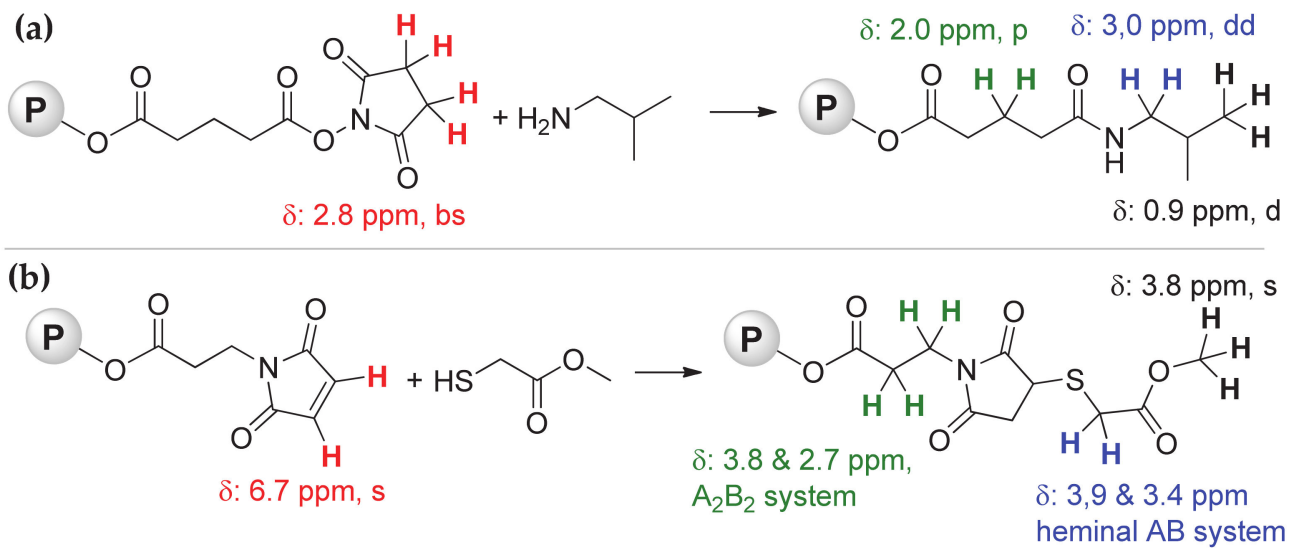

Scheme 3. Reactions of NHS- and MI-functionalized polymers with model amine and thiol, ${ }^{1} \mathrm{H}$ NMR criteria of the completion of the processes for NHS- and MI-terminated polymers, (a) and (b), respectively.

In the reaction of poly $(\varepsilon \mathrm{CL})-\mathbf{1}$ with ${ }^{\mathrm{i}} \mathrm{BuNH}_{2}$ in $\mathrm{CH}_{2} \mathrm{Cl}_{2}$ corresponding amide was obtained with total degree of amide functionalization $\sim 0.7$. Given the low accuracy of chainend group integration, $\varepsilon \mathrm{CL}$ /end groups ratio in the product poly $(\varepsilon C L)-1-N$ (Figure S26 in the Supplementary Materials) was in line with the ratio of $\varepsilon$ CL fragments, $\mathrm{BnO}$ and NHS groups in the starting polymer. The same result was achieved in the reaction of poly(L-LA)1 with ${ }^{\mathrm{i}} \mathrm{BuNH}_{2}$. Characteristic multiplicity of the signals of $-\mathrm{OC}(\mathrm{O}) \mathrm{CH}_{2}-$ in poly(L-LA)-1-N (Figure S27 in the Supplementary Materials) can be attributed to chirality of L-lactate fragment. These signals can be used in ${ }^{1} \mathrm{H}$ NMR spectral identification of poly(L-LA) 
covalent binding with biomedically significant amines when using NHS functionalization of poly(L-LA) by acyl chloride $\mathbf{1}$.

The reactions of water-soluble poly(EtEP)-1 and poly(EtOEP)-1 were conducted in aqueous media, purification of the substituted polymers from low MW impurities was made using dialysis of the polymer solutions. Degrees of amide functionalization were of the values of 0.7 and 0.4 for poly(EtEP)-1 and poly(EtOEP)-1, respectively, in relation to $\mathrm{BnO}$ fragment (Figures S28 and S30 in the Supplementary Materials). In this way, this approach is of limited effectiveness for covalent binding of NHS-functionalized poly(ethylene phosphate)s, obtained by termination of the ROP by acyl chloride 1 .

\subsection{Reactions of MI-Functionalized Polymers with Thiol-Containing Compounds}

Reaction of MI-functionalized compounds with thiols $[18,21]$ can be conducted in both organic [65] and aqueous [66,67] media similar to the reactions of NHS-functionalized compounds with amines. In our experiments, we chose $\mathrm{HSCH}_{2} \mathrm{COOMe}$ as a model thiol, the assignment of the signals in ${ }^{1} \mathrm{H}$ NMR spectra (Scheme $3 \mathrm{~b}$ ) was based on the previously reported data $[76,77]$.

The reactions of poly $(\varepsilon \mathrm{CL})-4$ and poly(L-LA)-4 with $\mathrm{HSCH}_{2} \mathrm{COOMe}$ were conducted in $\mathrm{CH}_{2} \mathrm{Cl}_{2}$. In both examples, the degree of thiol binding can be estimated as $\sim 0.8$ (Figures S32 and S33 in the Supplementary Materials). Even higher degree of thiol binding was reached for poly(EtEP)-4 in aqueous media (Figure S34 in the Supplementary Materials). This result is highly promising for the development of polymer-protein conjugates by the reaction of cysteine fragments in protein with MI-functionalized hydrophilic and biodegradable poly(ethylene phosphonate)s.

\section{Conclusions}

Termination of BHT-Mg catalyzed "living" ROP by functionalized acyl chlorides allowed to obtain NHS- and MI-containing polymers for different types of cyclic substrates: $\varepsilon C L$, L-LA, EtEP and EtOEP. When using of acyl chloride 1 the degree of NHS functionalization was almost quantitative for poly $(\varepsilon C L)$, poly $(L-L A)$, poly(EtEP) and poly(EtOEP). The results of the use of acyl chloride 4 were less successful for MI functionalization of poly $(\varepsilon C L)$, however, MI-terminated poly(L-LA) and poly(EtEP) were synthesized with almost quantitative yields.

Alternative approaches to functionalization, based on termination of BHT-Mg catalyzed ROP by conventional reagents (DSC or SA/N-hydroxysuccinimide/DCC), termination of TBD-catalyzed ROP by acyl chloride and on the reactions of -OH end-group containing polymers with acyl chloride, were not sufficiently effective.

The ability of NHS- and MI-functionalized polymers to further binding with amines and thiols without degradation of the polymer backbone was confirmed experimentally in model reactions with ${ }^{i} \mathrm{BuNH}_{2}$ and $\mathrm{HSCH}_{2} \mathrm{COOMe}$, respectively. These reactions were conducted in organic solvent $\left(\mathrm{CH}_{2} \mathrm{Cl}_{2}\right)$ and in aqueous media. End-group analysis of the ${ }^{1} \mathrm{H}$ NMR spectra showed no marked difference in comonomer/end group ratios for starting functionalized polymers and products of their further modification. Note that such analysis for the broad spectrum of functionalized polymers was performed for the first time ever.

In this way, suggested synthetic approach to NHS- and MI-functionalized polymers allows to synthesize high molecular weight products (DPn $=110-170)$, based on lactones, lactides, cyclic phosphonates, and cyclic phosphates, that are able to bind with amines and thiols, respectively. Relatively high MW values allow to consider these functionalized polymers as a base of chemically active polymer articles with a broad perspective of biomedical applications.

Supplementary Materials: The following are available online at https:/ /www.mdpi.com/2073-4 $360 / 13 / 6 / 868 / \mathrm{s} 1$, Figure S1: ${ }^{1} \mathrm{H}$ NMR spectrum $\left(400 \mathrm{MHz}, \mathrm{CDCl}_{3}, 20^{\circ} \mathrm{C}\right)$ of the acyl chloride $\mathbf{1}$, Figure S2: ${ }^{13} \mathrm{C}$ NMR spectrum $\left(101 \mathrm{MHz}, \mathrm{CDCl}_{3}, 20^{\circ} \mathrm{C}\right)$ of the acyl chloride 1, Figure S3: ${ }^{1} \mathrm{H}$ NMR spectrum $\left(400 \mathrm{MHz}, \mathrm{CDCl}_{3}, 20{ }^{\circ} \mathrm{C}\right)$ of the acyl chloride 2, Figure $\mathrm{S} 4:{ }^{13} \mathrm{C}$ NMR spectrum $(101 \mathrm{MHz}$, 
$\left.\mathrm{CDCl}_{3}, 20^{\circ} \mathrm{C}\right)$ of the acyl chloride 2, Figure S5: ${ }^{1} \mathrm{H} \mathrm{NMR}$ spectrum $\left(400 \mathrm{MHz}, \mathrm{CDCl}_{3}, 20^{\circ} \mathrm{C}\right)$ of the acyl chloride 3, Figure S6: ${ }^{13} \mathrm{C}$ NMR spectrum $\left(101 \mathrm{MHz}, \mathrm{CDCl}_{3}, 20^{\circ} \mathrm{C}\right)$ of the acyl chloride 3, Figure S7: ${ }^{1} \mathrm{H}$ NMR spectrum $\left(400 \mathrm{MHz}, \mathrm{CDCl}_{3}, 20{ }^{\circ} \mathrm{C}\right)$ of the acyl chloride 4, Figure S8: ${ }^{13} \mathrm{C}$ NMR spectrum $\left(101 \mathrm{MHz}, \mathrm{CDCl}_{3}, 20{ }^{\circ} \mathrm{C}\right)$ of the acyl chloride 4, Figure S9: ${ }^{1} \mathrm{H}$ NMR spectrum $\left(400 \mathrm{MHz}, \mathrm{CDCl}_{3}\right.$, $20{ }^{\circ} \mathrm{C}$ ) of NHS-terminated poly $(\varepsilon \mathrm{CL})$ (Table 1, Entry 1), Figure S10: ${ }^{1} \mathrm{H}$ NMR spectrum $(400 \mathrm{MHz}$, DMSO- $\mathrm{d}_{6}, 20^{\circ} \mathrm{C}$ ) of SA/NHS-terminated poly $(\varepsilon \mathrm{CL})$ (Table 1, Entry 2), Figure S11: ${ }^{1} \mathrm{H}$ NMR spectrum $\left(400 \mathrm{MHz}, \mathrm{CDCl}_{3}, 20^{\circ} \mathrm{C}\right)$ of acetyl-terminated poly(L-LA). Figure S12: ${ }^{1} \mathrm{H} \mathrm{NMR}$ spectrum $(400 \mathrm{MHz}$, $\left.\mathrm{CDCl}_{3}, 2{ }^{\circ} \mathrm{C}\right)$ of poly $(\varepsilon \mathrm{CL})-\mathbf{1}$ (Table 1, Entry 3), Figure S13: ${ }^{1} \mathrm{H} \mathrm{NMR}$ spectrum $\left(400 \mathrm{MHz}, \mathrm{CDCl}_{3}\right.$, $\left.20{ }^{\circ} \mathrm{C}\right)$ of poly $(\varepsilon \mathrm{CL})-2$ (Table 1, Entry 4), Figure S14: ${ }^{1} \mathrm{H}$ NMR spectrum $\left(400 \mathrm{MHz}, \mathrm{CDCl}_{3}, 20^{\circ} \mathrm{C}\right)$ of poly( $\varepsilon C L)-3$ (Table 1, Entry 5), Figure S15: ${ }^{1} \mathrm{H}$ NMR spectrum ( $400 \mathrm{MHz}, \mathrm{CDCl}_{3}, 20^{\circ} \mathrm{C}$ ) of poly $(\varepsilon \mathrm{CL})-4$ (Table 1, Entry 6), Figure S16: ${ }^{1} \mathrm{H}$ NMR spectrum $\left(400 \mathrm{MHz}, \mathrm{CDCl}_{3}, 2{ }^{\circ} \mathrm{C}\right.$ ) of poly(L-LA)-1 (Table 1, Entry 7), Figure S17: ${ }^{1} \mathrm{H}$ NMR spectrum $\left(400 \mathrm{MHz}, \mathrm{CDCl}_{3}, 2{ }^{\circ} \mathrm{C}\right)$ of poly(L-LA)-4 (Table 1, Entry 8), Figure S18: ${ }^{1} \mathrm{H}$ NMR spectrum $\left(400 \mathrm{MHz}, \mathrm{CDCl}_{3}, 2{ }^{\circ} \mathrm{C}\right)$ of poly(EtEP)-1 (Table 1, Entry 9), Figure S19: ${ }^{1} \mathrm{H}$ NMR spectrum $\left(400 \mathrm{MHz}, \mathrm{CDCl}_{3}, 20{ }^{\circ} \mathrm{C}\right.$ ) of poly(EtEP)-4 (Table 1, Entry 10), Figure S20: ${ }^{1} \mathrm{H}$ NMR spectrum $\left(400 \mathrm{MHz}, \mathrm{CDCl}_{3}, 20^{\circ} \mathrm{C}\right)$ of poly $(\varepsilon \mathrm{CL})-b$-poly(EtEP)-1 (Table 1, Entry 11), Figure S21: ${ }^{1} \mathrm{H}$ NMR spectrum $\left(400 \mathrm{MHz}, \mathrm{CDCl}_{3}, 20^{\circ} \mathrm{C}\right.$ ) of poly $(\varepsilon \mathrm{CL})-b$-poly(EtEP)-4 (Table 1, Entry 12), Figure S22: ${ }^{1} \mathrm{H}$ NMR spectrum $\left(400 \mathrm{MHz}, \mathrm{CDCl}_{3}, 20{ }^{\circ} \mathrm{C}\right)$ of poly(EtOEP)-1 (Table 1, Entry 13), Figure S23: ${ }^{1} \mathrm{H}$ NMR spectrum $\left(400 \mathrm{MHz}, \mathrm{CDCl}_{3}, 20^{\circ} \mathrm{C}\right)$ of poly(EtOEP)-1 obtained using TBD/BnOH initiation, Figure S24: ${ }^{1} \mathrm{H}$ NMR spectrum $\left(400 \mathrm{MHz}, \mathrm{CDCl}_{3}, 20{ }^{\circ} \mathrm{C}\right)$ of NHS-functionalized poly( $(\varepsilon \mathrm{CL}) \mathrm{ob}-$ tained by the reaction of acyl chloride 1 with poly $(\varepsilon C L)$, Figure S25: ${ }^{1} \mathrm{H}$ NMR spectrum $(400 \mathrm{MHz}$, $\mathrm{CDCl}_{3}, 20^{\circ} \mathrm{C}$ ) of NHS-functionalized poly(EtOEP) obtained by the reaction of acyl chloride $\mathbf{1}$ with poly(EtOEP). Figure S26: ${ }^{1} \mathrm{H}$ NMR spectrum $\left(400 \mathrm{MHz}, \mathrm{CDCl}_{3}, 20{ }^{\circ} \mathrm{C}\right)$ of poly $(\varepsilon \mathrm{CL})-\mathbf{1}-\mathrm{N}$, Figure S27: ${ }^{1} \mathrm{H}$ NMR spectrum $\left(400 \mathrm{MHz}, \mathrm{CDCl}_{3}, 20{ }^{\circ} \mathrm{C}\right)$ of poly(L-LA)-1-N, Figure S28: ${ }^{1} \mathrm{H}$ NMR spectrum $\left(400 \mathrm{MHz}, \mathrm{CDCl}_{3}, 20^{\circ} \mathrm{C}\right)$ of poly(EtEP)-1-N, Figure S29: ${ }^{31} \mathrm{P}$ NMR spectrum $\left(162 \mathrm{MHz}, \mathrm{CDCl}_{3}, 20^{\circ} \mathrm{C}\right)$ of poly(EtEP)-1-N, Figure S30: ${ }^{1} \mathrm{H}$ NMR spectrum $\left(400 \mathrm{MHz}, \mathrm{CDCl}_{3}, 20{ }^{\circ} \mathrm{C}\right.$ ) of poly(EtOEP)-1-N, Figure S31: ${ }^{31} \mathrm{P}$ NMR spectrum $\left(162 \mathrm{MHz}, \mathrm{CDCl}_{3}, 20{ }^{\circ} \mathrm{C}\right)$ of poly(EtOEP)-1-N, Figure S32: ${ }^{1} \mathrm{H}$ NMR spectrum $\left(400 \mathrm{MHz}, \mathrm{CDCl}_{3}, 20^{\circ} \mathrm{C}\right)$ of poly $(\varepsilon \mathrm{CL})-4-\mathrm{S}$, Figure $\mathrm{S} 33:{ }^{1} \mathrm{H} \mathrm{NMR}$ spectrum $\left(400 \mathrm{MHz}, \mathrm{CDCl}_{3}\right.$, $20{ }^{\circ} \mathrm{C}$ ) of poly(L-LA)-4-S, Figure S34: ${ }^{1} \mathrm{H}$ NMR spectrum $\left(400 \mathrm{MHz}, \mathrm{CDCl}_{3}, 20{ }^{\circ} \mathrm{C}\right)$ of poly(EtEP)-4-S, Figure S35: ${ }^{31} \mathrm{P} \mathrm{NMR}$ spectrum $\left(162 \mathrm{MHz}, \mathrm{CDCl}_{3}, 20^{\circ} \mathrm{C}\right)$ of poly(EtEP)-4-S.

Author Contributions: Conceptualization, I.N. and A.S.; methodology, A.S. and P.I.; validation, I.N., A.S. and P.I.; formal analysis, P.I.; investigation, A.S., V.B., E.S. and A.T.; resources, I.N. and A.S.; writing-original draft preparation, A.S. and P.I.; writing—review and editing, I.N. and P.I.; visualization, P.I.; supervision, I.N. and A.S.; project administration, A.S.; funding acquisition, A.S. All authors have read and agreed to the published version of the manuscript.

Funding: This research was funded by the Russian Science Foundation, grant number 18-73-10069, and was carried out within the State Program of TIPS RAS (in part of polymer analysis).

Institutional Review Board Statement: Not applicable.

Informed Consent Statement: Not applicable.

Data Availability Statement: The data presented in this study are available on request from the corresponding author.

Acknowledgments: The authors are grateful for the use of the equipment of the TIPS RAS Center of Collective Use: "New petrochemical processes, polymer composites and adhesives".

Conflicts of Interest: The authors declare no conflict of interest.

\section{References}

1. Ulery, B.D.; Nair, L.S.; Laurencin, C.T. Biomedical applications of biodegradable polymers. J. Polym. Sci. Part B Polym. Phys. 2011, 49, 832-864. [CrossRef]

2. Vroman, I.; Tighzert, L. Biodegradable Polymers. Materials 2009, 2, 307-344. [CrossRef]

3. Englert, C.; Brendel, J.C.; Majdanski, T.C.; Yildirim, T.; Schubert, S.; Gottschaldt, M.; Windhab, N.; Schubert, U.S. Pharmapolymers in the 21st century: Synthetic polymers in drug delivery applications. Prog. Polym. Sci. 2018, 87, 107-164. [CrossRef]

4. Agarwal, S. Biodegradable Polymers: Present Opportunities and Challenges in Providing a Microplastic-Free Environment. Macromol. Chem. Phys. 2020, 221, 2000017. [CrossRef]

5. Iha, R.K.; Wooley, K.L.; Nyström, A.M.; Burke, D.J.; Kade, M.J.; Hawker, C.J. Applications of Orthogonal “Click” Chemistries in the Synthesis of Functional Soft Materials. Chem. Rev. 2009, 109, 5620-5686. [CrossRef] [PubMed] 
6. Gauthier, M.A.; Klok, H.-A. Peptide/protein-polymer conjugates: Synthetic strategies and design concepts. Chem. Commun. 2008, 2591-2611. [CrossRef] [PubMed]

7. Theato, P. Synthesis of well-defined polymeric activated esters. J. Polym. Sci. Part A: Polym. Chem. 2008, 46, 6677-6687. [CrossRef]

8. Seyednejad, H.; Ghassemi, A.H.; van Nostrum, C.F.; Vermonden, T.; Hennink, W.E. Functional aliphatic polyesters for biomedical and pharmaceutical applications. J. Control. Release 2011, 152, 168-176. [CrossRef]

9. Arslan, M.; Gevrek, T.; Sanyal, A.; Shunmugam, R. Maleimide Containing Thiol-Reactive Polymers: Synthesis and Functionalization. In Functional Polymers; CRC Press: Boca Raton, FL, USA, 2017; pp. 265-293.

10. Sadaba, N.; Salsamendi, M.; Casado, N.; Zuza, E.; Muñoz, J.; Sarasua, J.-R.; Mecerreyes, D.; Mantione, D.; Detrembleur, C.; Sardon, H. Catechol End-Functionalized Polylactide by Organocatalyzed Ring-Opening Polymerization. Polymers 2018, 10, 155. [CrossRef] [PubMed]

11. Grossen, P.; Witzigmann, D.; Sieber, S.; Huwyler, J. PEG-PCL-based nanomedicines: A biodegradable drug delivery system and its application. J. Control. Release 2017, 260, 46-60. [CrossRef]

12. Ravasco, J.M.; Faustino, H.; Trindade, A.; Gois, P.M.P. Bioconjugation with Maleimides: A Useful Tool for Chemical Biology. Chem. - A Eur. J. 2019, 25, 43-59. [CrossRef]

13. Spicer, C.D.; Pashuck, E.T.; Stevens, M.M. Achieving Controlled Biomolecule-Biomaterial Conjugation. Chem. Rev. 2018, 118, 7702-7743. [CrossRef] [PubMed]

14. Kim, J.; Jung, H.Y.; Park, M.J. End-Group Chemistry and Junction Chemistry in Polymer Science: Past, Present, and Future. Macromolecules 2020, 53, 746-763. [CrossRef]

15. Northrop, B.H.; Frayne, S.H.; Choudhary, U. Thiol-maleimide "click" chemistry: Evaluating the influence of solvent, initiator, and thiol on the reaction mechanism, kinetics, and selectivity. Polym. Chem. 2015, 6, 3415-3430. [CrossRef]

16. Lim, C.Y.; Owens, N.A.; Wampler, R.D.; Ying, Y.; Granger, J.H.; Porter, M.D.; Takahashi, M.; Shimazu, K. Succinimidyl Ester Surface Chemistry: Implications of the Competition between Aminolysis and Hydrolysis on Covalent Protein Immobilization. Langmuir 2014, 30, 12868-12878. [CrossRef] [PubMed]

17. Beck, A.; Goetsch, L.; Dumontet, C.; Corvaïa, N. Strategies and challenges for the next generation of antibody-drug conjugates. Nat. Rev. Drug Discov. 2017, 16, 315-337. [CrossRef] [PubMed]

18. Pounder, R.J.; Stanford, M.J.; Brooks, P.; Richards, S.P.; Dove, A.P. Metal free thiol-maleimide 'Click' reaction as a mild functionalisation strategy for degradable polymers. Chem. Commun. 2008, 5158-5160. [CrossRef] [PubMed]

19. Hermanson, G.T. Bioconjugate Techniques; Elsevier: Amsterdam, The Netherlands, 2013.

20. Nair, D.P.; Podgórski, M.; Chatani, S.; Gong, T.; Xi, W.; Fenoli, C.R.; Bowman, C.N. The Thiol-Michael Addition Click Reaction: A Powerful and Widely Used Tool in Materials Chemistry. Chem. Mater. 2014, 26, 724-744. [CrossRef]

21. Hoyle, C.E.; Bowman, C.N. Thiol-Ene Click Chemistry. Angew. Chem. Int. Ed. 2010, 49, 1540-1573. [CrossRef]

22. Bednarek, M. Coupling reaction with thiols as the efficient method of functionalization of "clickable" polylactide. React. Funct. Polym. 2013, 73, 1130-1136. [CrossRef]

23. Lowe, A.B. Thiolene "click" reactions and recent applications in polymer and materials synthesis. Polym. Chem. 2010, 1, 17-36. [CrossRef]

24. Lowe, A.B. Thiol-ene "click" reactions and recent applications in polymer and materials synthesis: A first update. Polym. Chem. 2014, 5, 4820-4870. [CrossRef]

25. Koniev, O.; Wagner, A. Developments and recent advancements in the field of endogenous amino acid selective bond forming reactions for bioconjugation. Chem. Soc. Rev. 2015, 44, 5495-5551. [CrossRef]

26. Albertsson, A.-C.; Varma, I.K. Recent Developments in Ring Opening Polymerization of Lactones for Biomedical Applications. Biomacromolecules 2003, 4, 1466-1486. [CrossRef]

27. Kamber, N.E.; Jeong, W.; Waymouth, R.M.; Pratt, R.C.; Lohmeijer, B.G.G.; Hedrick, J.L. Organocatalytic Ring-Opening Polymerization. Chem. Rev. 2007, 107, 5813-5840. [CrossRef] [PubMed]

28. Jérôme, C.; LeComte, P. Recent advances in the synthesis of aliphatic polyesters by ring-opening polymerization. Adv. Drug Deliv. Rev. 2008, 60, 1056-1076. [CrossRef] [PubMed]

29. LeComte, P.; Jérôme, C. Recent Developments in Ring-Opening Polymerization of Lactones. Adv. Polym. Sci. 2011, 245, 173-217. [CrossRef]

30. Dove, A.P. Controlled ring-opening polymerisation of cyclic esters: Polymer blocks in self-assembled nanostructures. Chem. Commun. 2008, 6446-6470. [CrossRef] [PubMed]

31. Olsén, P.; Odelius, K.; Albertsson, A.-C. Thermodynamic Presynthetic Considerations for Ring-Opening Polymerization. Biomacromolecules 2016, 17, 699-709. [CrossRef] [PubMed]

32. Nifant'Ev, I.; Ivchenko, P. Coordination Ring-Opening Polymerization of Cyclic Esters: A Critical Overview of DFT Modeling and Visualization of the Reaction Mechanisms. Molecules 2019, 24, 4117. [CrossRef]

33. Nifant'Ev, I.; Ivchenko, P. DFT Modeling of Organocatalytic Ring-Opening Polymerization of Cyclic Esters: A Crucial Role of Proton Exchange and Hydrogen Bonding. Polymers 2019, 11, 2078. [CrossRef]

34. Guillaume, S.M.; Kirillov, E.; Sarazin, Y.; Carpentier, J.-F. Beyond Stereoselectivity, Switchable Catalysis: Some of the Last Frontier Challenges in Ring-Opening Polymerization of Cyclic Esters. Chem. A Eur. J. 2015, 21, 7988-8003. [CrossRef] [PubMed]

35. Gao, J.; Zhu, D.; Zhang, W.; Solan, G.A.; Ma, Y.; Sun, W.-H. Recent progress in the application of group 1, 2 \& 13 metal complexes as catalysts for the ring opening polymerization of cyclic esters. Inorg. Chem. Front. 2019, 6, 2619-2652. [CrossRef] 
36. Miron, T.; Wilchek, M. A simplified method for the preparation of succinimidyl carbonate polyethylene glycol for coupling to proteins. Bioconjugate Chem. 1993, 4, 568-569. [CrossRef]

37. Steinbach, T.; Wurm, F.R. Degradable Polyphosphoester-Protein Conjugates: "PPEylation" of Proteins. Biomacromolecules 2016, 17, 3338-3346. [CrossRef]

38. Schöttler, S.; Becker, G.; Winzen, S.; Steinbach, T.; Mohr, K.; Landfester, K.; Mailänder, S.S.V.; Wurm, F.R. Protein adsorption is required for stealth effect of poly(ethylene glycol)- and poly(phosphoester)-coated nanocarriers. Nat. Nanotechnol. 2016, 11, 372-377. [CrossRef] [PubMed]

39. Shuai, X.; Merdan, T.; Unger, F.; Wittmar, A.M.; Kissel, T. Novel Biodegradable Ternary Copolymershy-PEI-g-PCL-b-PEG: Synthesis, Characterization, and Potential as Efficient Nonviral Gene Delivery Vectors. Macromolecules 2003, 36, 5751-5759. [CrossRef]

40. Steinbach, T.; Becker, G.; Spiegel, A.; Figueiredo, T.; Russo, D.; Wurm, F.R. Reversible Bioconjugation: Biodegradable Poly(phosphate)-Protein Conjugates. Macromol. Biosci. 2016, 17, 1600377. [CrossRef]

41. Ji, S.; Zhu, Z.; Hoye, T.R.; Macosko, C.W. Maleimide Functionalized Poly(e-caprolactone)-block-poly(ethylene glycol) (PCL-PEGMAL): Synthesis, Nanoparticle Formation, and Thiol Conjugation. Macromol. Chem. Phys. 2009, 210, 823-831. [CrossRef]

42. Pelosi, C.; Duce, C.; Russo, D.; Tiné, M.R.; Wurm, F.R. PPEylation of proteins: Synthesis, activity, and stability of myoglobinpolyphosphoester conjugates. Eur. Polym. J. 2018, 108, 357-363. [CrossRef]

43. Pelosi, C.; Tinè, M.R.; Wurm, F.R. Main-chain water-soluble polyphosphoesters: Multi-functional polymers as degradable PEG-alternatives for biomedical applications. Eur. Polym. J. 2020, 141, 110079. [CrossRef]

44. Russo, D.; De Angelis, A.; Garvey, C.J.; Wurm, F.R.; Appavou, M.-S.; Prevost, S. Effect of Polymer Chain Density on ProteinPolymer Conjugate Conformation. Biomacromolecules 2019, 20, 1944-1955. [CrossRef]

45. Stanford, M.J.; Dove, A.P. One-Pot Synthesis of $\alpha, \omega$-Chain End Functional, Stereoregular, Star-Shaped Poly(lactide). Macromolecules 2009, 42, 141-147. [CrossRef]

46. Stanford, M.J.; Pflughaupt, R.L.; Dove, A.P. Synthesis of Stereoregular Cyclic Poly(lactide)s via “Thiol-Ene" Click Chemistry. Macromolecules 2010, 43, 6538-6541. [CrossRef]

47. Nifant'Ev, I.E.; Shlyakhtin, A.V.; Tavtorkin, A.N.; Ivchenko, P.V.; Borisov, R.S.; Churakov, A.V. Monomeric and dimeric magnesium mono-BHT complexes as effective ROP catalysts. Catal. Commun. 2016, 87, 106-111. [CrossRef]

48. Ivchenko, P.V.; Shlyakhtin, A.V.; Nifant'Ev, I.E. Ring-opening polymerization of glycolide and rac -lactide, catalyzed by aryloxy magnesium complexes: DFT study of reaction profile and stereocontrol mechanism. Mendeleev Commun. 2017, 27, 278-280. [CrossRef]

49. Nifant'Ev, I.E.; Shlyakhtin, A.V.; Bagrov, V.V.; Komarov, P.D.; Kosarev, M.A.; Tavtorkin, A.N.; Minyaev, M.E.; Roznyatovsky, V.A.; Ivchenko, P.V. Controlled ring-opening polymerisation of cyclic phosphates, phosphonates and phosphoramidates catalysed by heteroleptic BHT-alkoxy magnesium complexes. Polym. Chem. 2017, 8, 6806-6816. [CrossRef]

50. Nifant'Ev, I.E.; Shlyakhtin, A.V.; Bagrov, V.V.; Minyaev, M.E.; Churakov, A.V.; Karchevsky, S.G.; Birin, K.P.; Ivchenko, P.V. Mono-BHT heteroleptic magnesium complexes: Synthesis, molecular structure and catalytic behavior in the ring-opening polymerization of cyclic esters. Dalton Trans. 2017, 46, 12132-12146. [CrossRef]

51. Nifant'Ev, I.E.; Shlyakhtin, A.V.; Bagrov, V.V.; Komarov, P.D.; Kosarev, M.A.; Tavtorkin, A.N.; Minyaev, M.E.; Roznyatovsky, V.A.; Ivchenko, P.V. Synthesis and ring-opening polymerization of glycidyl ethylene phosphate with a formation of linear and branched polyphosphates. Mendeleev Commun. 2018, 28, 155-157. [CrossRef]

52. Nifant'Ev, I.E.; Shlyakhtin, A.V.; Bagrov, V.V.; Komarov, P.D.; Tavtorkin, A.N.; Minyaev, M.E.; Kosarev, M.A.; Ivchenko, P.V. Synthesis in aqueous media of poly(ethylene phosphoric acids) by mild thermolysis of homopolymers and block copolymers based on tert -butyl ethylene phosphate. Eur. Polym. J. 2018, 106, 249-256. [CrossRef]

53. Nifant'Ev, I.; Shlyakhtin, A.; Kosarev, M.; Karchevsky, S.; Ivchenko, P. Mechanistic Insights of BHT-Mg-Catalyzed Ethylene Phosphate's Coordination Ring-Opening Polymerization: DFT Modeling and Experimental Data. Polymers 2018, $10,1105$. [CrossRef]

54. Nifant'Ev, I.; Shlyakhtin, A.; Kosarev, M.; Gavrilov, D.; Karchevsky, S.; Ivchenko, P. DFT Visualization and Experimental Evidence of BHT-Mg-Catalyzed Copolymerization of Lactides, Lactones and Ethylene Phosphates. Polymers 2019, 11, 1641. [CrossRef]

55. Nifant'Ev, I.; Komarov, P.; Ovchinnikova, V.; Kiselev, A.; Minyaev, M.; Ivchenko, P. Comparative Experimental and Theoretical Study of $\mathrm{Mg}$, $\mathrm{Al}$ and $\mathrm{Zn}$ Aryloxy Complexes in Copolymerization of Cyclic Esters: The Role of the Metal Coordination in Formation of Random Copolymers. Polymers 2020, 12, 2273. [CrossRef]

56. Dar'In, D.; Bakulina, O.; Chizhova, M.; Krasavin, M. New Heterocyclic Product Space for the Castagnoli-Cushman ThreeComponent Reaction. Org. Lett. 2015, 17, 3930-3933. [CrossRef] [PubMed]

57. Baumhover, N.J.; Anderson, K.; Fernandez, C.A.; Rice, K.G. Synthesis and In Vitro Testing of New Potent Polyacridine-Melittin Gene Delivery Peptides. Bioconjugate Chem. 2009, 21, 74-83. [CrossRef] [PubMed]

58. Sinclair, A.J.; Del Amo, V.; Philp, D. Structure-reactivity relationships in a recognition mediated [3+2] dipolar cycloaddition reaction. Org. Biomol. Chem. 2009, 7, 3308-3318. [CrossRef] [PubMed]

59. Wolf, T.; Steinbach, T.; Wurm, F.R. A Library of Well-Defined and Water-Soluble Poly(alkyl phosphonate)s with Adjustable Hydrolysis. Macromolecules 2015, 48, 3853-3863. [CrossRef]

60. Steinbach, T.; Schröder, R.; Ritz, S.; Wurm, F.R. Microstructure analysis of biocompatible phosphoester copolymers. Polym. Chem. 2013, 4, 4469-4479. [CrossRef] 
61. Nifant'Ev, I.; Shlyakhtin, A.; Bagrov, V.; Lozhkin, B.; Zakirova, G.; Ivchenko, P.; Legon'Kova, O. Theoretical and experimental studies of 1,5,7-triazabicyclo[4.4.0]dec-5-ene-catalyzed ring opening/ring closure reaction mechanism for 5-, 6- and 7-membered cyclic esters and carbonates. React. Kinet. Mech. Catal. 2015, 117, 447-476. [CrossRef]

62. Liu, X.X.; Melman, A. Templated alkylation of hexahistidine with Baylis-Hillman esters. Chem. Commun. 2013, 49, 9042-9044. [CrossRef]

63. Corrie, J.E.T.; Trentham, D.R. Synthesis of photoactivatable fluorescein derivatives bearing side chains with varying properties. J. Chem. Soc. Perkin Trans. 1 1995, 1, 1993-2000. [CrossRef]

64. Camper, N.; Scott, C.J.; Migaud, M.E. Synthesis of an analogue of the bisphosphonate drug Ibandronate for targeted drug-delivery therapeutic strategies. New J. Chem. 2010, 34, 949-955. [CrossRef]

65. Hoang, M.-D.; Kumar, R.A.; Buisson, D.A.; Ling, W.L.; Gravel, E.; Doris, E.; Ramar, A.K. Self-assembled Polydiacetylene Nanoribbons for Semi-heterogeneous and Enantioselective Organocatalysis of Aldol Reactions in Water. ChemCatChem 2019, 12, 1156-1160. [CrossRef]

66. Wang, D.; Cao, Y.; Zheng, L.; Lv, D.; Chen, L.; Xing, X.; Zhu, Z.; Li, X.; Chai, Y. Identification of Annexin A2 as a target protein for plant alkaloid matrine. Chem. Commun. 2017, 53, 5020-5023. [CrossRef]

67. Tian, D.-M.; Qiao, J.; Bao, Y.-Z.; Liu, J.; Zhang, X.-K.; Sun, X.-L.; Zhang, Y.-W.; Yao, X.-S.; Tang, J.-S. Design and synthesis of biotinylated cardiac glycosides for probing Nur77 protein inducting pathway. Bioorganic Med. Chem. Lett. 2019, 29, 707-712. [CrossRef]

68. Yao, Y.; Yu, L.; Su, X.; Wang, Y.; Li, W.; Wu, Y.; Cheng, X.; Zhang, H.; Wei, X.; Chen, H.; et al. Synthesis, characterization and targeting chemotherapy for ovarian cancer of trastuzumab-SN-38 conjugates. J. Control. Release 2015, 220, 5-17. [CrossRef]

69. Attatsi, I.K.; Zhu, W.; Liang, X. Noncovalent immobilization of Co(ii)porphyrin through axial coordination as an enhanced electrocatalyst on carbon electrodes for oxygen reduction and evolution. New J. Chem. 2020, 44, 4340-4345. [CrossRef]

70. Yildırım, A. Surfactant-Catalyzed Addition of Higher Thiols to N-Aryl Substituted Maleimides. Synth. Commun. 2014, 44, 1137-1141. [CrossRef]

71. Grin, M.A.; Brusov, S.S.; Shchepelina, E.Y.; Ponomarev, P.V.; Khrenova, M.K.; Smirnov, A.S.; Lebedeva, V.S.; Mironov, A.F. Conjugates of natural chlorins with cyclen as chelators of transition metals. Mendeleev Commun. 2017, 27, 338-340. [CrossRef]

72. Minyaev, M.E.; Nifant'Ev, I.E.; Shlyakhtin, A.V.; Ivchenko, P.V.; Lyssenko, K.A. Phenoxide and alkoxide complexes of Mg, $\mathrm{Al}$ and $\mathrm{Zn}$, and their use for the ring-opening polymerization of $\in$-caprolactone with initiators of different natures. Acta Crystallogr. Sect. C Struct. Chem. 2018, 74, 548-557. [CrossRef] [PubMed]

73. Minyaev, M.E.; Churakov, A.V.; Nifant'Ev, I.E. Structural diversity of polynuclear Mg x O y cores in magnesium phenoxide complexes. Acta Crystallogr. Sect. C Struct. Chem. 2017, 73, 854-861. [CrossRef]

74. Odinokov, V.N.; Akhmetova, V.R.; Botsman, L.P.; Tolstikov, G.A.; Moiseenkov, A.M. Insect pheromones and their analogs. XI. Synthesis of 2,6-dimethylhepta-1,6-dien-3-ol acetate? The sex attractant ofPseudococcus comstocki. Chem. Nat. Compd. 1985, 21, 243-244. [CrossRef]

75. Liu, J.; Ma, D. A Unified Approach for the Assembly of Atisine- and Hetidine-type Diterpenoid Alkaloids: Total Syntheses of Azitine and the Proposed Structure of Navirine C. Angew. Chem. Int. Ed. 2018, 57, 6676-6680. [CrossRef] [PubMed]

76. An, Y.-L.; Deng, Y.-X.; Zhang, W.; Zhao, S.-Y. Regioselective Hetero-Michael Addition of Oxygen, Sulfur, and Nitrogen Nucleophiles to Maleimides Catalyzed by BF3.OEt2. Synthesis 2015, 47, 1581-1592. [CrossRef]

77. Lin, Y.-M.; Lu, G.-P.; Cai, C.; Yi, W.-B. An odorless thia-Michael addition using Bunte salts as thiol surrogates. RSC Adv. 2015, 5, 27107-27111. [CrossRef] 